
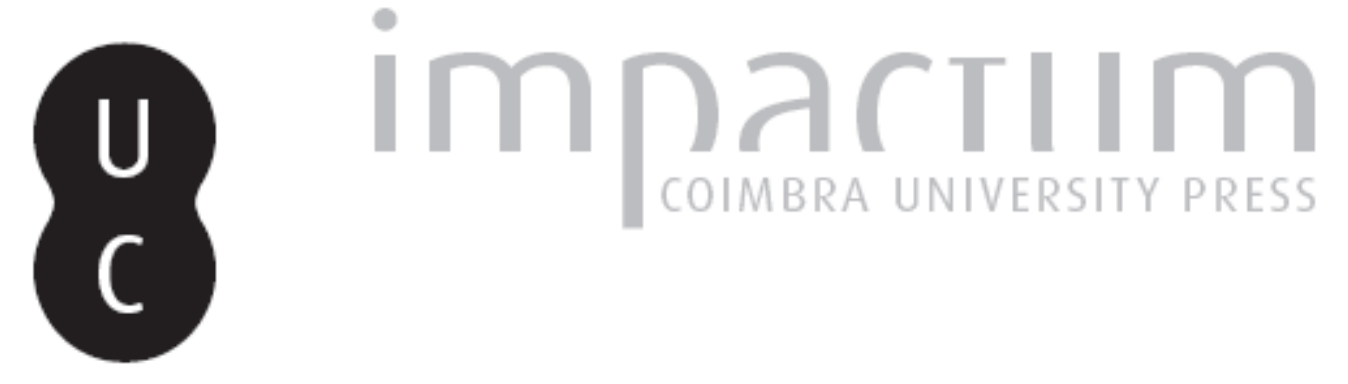

\title{
A construção da vivência da paixão nas Lettres portugaises: aspectos da semântica literária, médica e moral
}

Autor(es): $\quad$ Carvalho, Cláudio Alexandre

Publicado por: Imprensa da Universidade de Coimbra

URL

persistente:

URI:http://hdl.handle.net/10316.2/35459

DOI:

DOI:http://dx.doi.org/10.14195/0870-4112_11_4

Accessed : $\quad$ 26-Apr-2023 14:42:28

A navegação consulta e descarregamento dos títulos inseridos nas Bibliotecas Digitais UC Digitalis, UC Pombalina e UC Impactum, pressupõem a aceitação plena e sem reservas dos Termos e Condições de Uso destas Bibliotecas Digitais, disponíveis em https://digitalis.uc.pt/pt-pt/termos.

Conforme exposto nos referidos Termos e Condições de Uso, o descarregamento de títulos de acesso restrito requer uma licença válida de autorização devendo o utilizador aceder ao(s) documento(s) a partir de um endereço de IP da instituição detentora da supramencionada licença.

Ao utilizador é apenas permitido o descarregamento para uso pessoal, pelo que o emprego do(s) título(s) descarregado(s) para outro fim, designadamente comercial, carece de autorização do respetivo autor ou editor da obra.

Na medida em que todas as obras da UC Digitalis se encontram protegidas pelo Código do Direito de Autor e Direitos Conexos e demais legislação aplicável, toda a cópia, parcial ou total, deste documento, nos casos em que é legalmente admitida, deverá conter ou fazer-se acompanhar por este aviso.

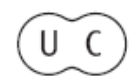




\section{ESTÉTICA E POLÍTICA}

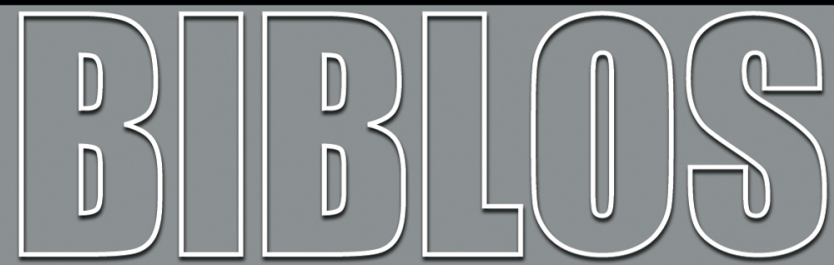

REVISTA DA FACULDADE DE LETRAS UNIVERSIDADE DE COIMBRA 
Biblos, n. s. XI (2013) 75-120

DOI: http://dx.doi.org/10.14195/0870-4112_11_4

Cláudio Alexandre S. Carvalho

Unidade I\&D LIF, Faculdade de Letras da Universidade de Coimbra

Bolseiro UC/FCT

\title{
A CONSTRUÇÃO DA VIVÊNCIA DA PAIXÃO \\ NAS LETTRES PORTUGAISES. ASPECTOS DA SEMÂNTICA \\ LITERÁRIA, MÉDICA E MORAL
}

\section{Resumo}

No presente artigo sustenta-se que as Lettres Portugaises não são redutíveis à sua dimensão literária e permitem, em virtude da sua peculiar composição, aceder a temas e conflitos inerentes à transição para a sociedade moderna. A sua contribuição para o desenvolvimento do romance epistolar é frequentemente notada, sublinhando-se como a narração da vivência da paixão garante um acréscimo de autenticidade desse género literário. À margem da questão autoral, o texto é exemplar da função do romance não como representação ou mimesis da realidade mas como espaço de criação assente na forma autobiográfica de narração. Nas Lettres é a partir da conjugação entre as observações em primeira e em segunda ordem que se articulam formas pré-adaptativas fornecidas pelo amor-paixão. Sustenta-se que a excepcionalidade das Lettres depende da verosimilhança da sua apresentação dos movimentos da paixão, em conformidade 1) com a imposição gradual de um novo paradigma fisiológico, 2) a evolução da Psicologia moral ao longo do século XVII e 3) com o avanço da estética literária com recurso à observação de segunda ordem. Parte de um conjunto mais vasto de mutações sociais, a constituição de um código da intimidade depende da valorização da "interioridade" subjectiva e sua observação do acoplamento entre a sensibilidade, sentimento e emoção (paixões da alma) e suas formas sociais.

Palavras-Chave: Semântica do amour-passion, Literatura epistolar, Sensibilidade, Melancolia erótica, Terapia.

\begin{abstract}
In the present article we hold that, due to their peculiar composition, which grants access to themes and conflicts inherent to the transition towards modern society, the Lettres Portugaises cannot be reduced to their literary dimension.
\end{abstract}


Their contribution to the development of epistolary novel is frequently noted, underlining how first person narration of the experience of passion warrants an increased authenticity to the genre. Besides the question of authorship, the text exemplifies the function of the novel not as representation or mimesis of reality but as a space for creation based in the autobiographical form of narrative. In the Lettres it is through the conjugation between first and second order observations that pre-adaptive forms of passionate love are put forward. It is argued that the exceptionality of the Lettres depends on the verisimilitude of the presentation of passions motions, according to 1) the gradual imposition of a new physiological paradigm, 2) the evolution of moral Psychology along the $17^{\text {th }}$ century and 3 ) the advancement of literary aesthetics recurring to second order observation. Part of a wider set of social mutations, the constitution of a code of intimacy depends on the valuing of subjective "innerness" and its observation of the coupling between sensitivity, emotions and sentiments (passions of the soul) and their social forms.

Keywords: Semantics of passionate love, Epistolary literature, Sensitivity, Erotic Melancholy, Therapy. 


\section{Introdução}

Tendo em conta a importância que as paixões assumiram no debate médico e filosófico da relação entre mente e corpo, nos cruzamentos semânticos entre a Psicologia moral e a Gnosiologia e na Literatura com o delinear da novela como género, é possível afirmar que o Grand Siècle é o século das paixões. As grandes obras de Pufendorf, Descartes, Hobbes, Espinosa e Locke assentam numa refletida adaptação das doutrinas estóica e sensualista relativa ao valor da paixão fonte de conhecimento sensível e das auto-afecções, bem como à avaliação e do prazer, em todos os domínios da vida individual e social da espécie humana. Verifica-se por vezes uma tendência para obliterar, ou pelo menos desvincular daquelas reflexões filosóficas, por um lado o tratamento médico-fisiológico e por outro a integração das paixões na emergente cultura literata. Em virtude da atenção renovada que a modernidade presta à especificidade de certas condições mentais, o médico e o literário, sobretudo o poético, tiveram pontos de contacto intenso integrando a procura de compreensão e tratamento das paixões, e entre elas a amorosa ou erótica. Neste artigo procura avaliar-se de que modo é que o "desdobramento" da paixão que encontramos nas Lettres Portugaises beneficia dessa conjugação de avanços da teoria (e terapêutica) médica e literária das paixões que remontam aos finais do século XVI. Esse percurso permitirá a aproximação a alguns aspectos das Lettres que tornam difícil a sua acomodação no curso daquilo que se convencionou chamar de história das ideias.

A teoria da estética, em particular da estética literária dos séculos XVII e XVIII, requer indubitavelmente a compreensão dos mecanismos da sensibilidade, dos movimentos emocionais e seus correlatos imaginativos e cognitivos, pelo menos a dois níveis. O primeiro prende-se com a sequência temporal da diegese, permitindo aceder à densidade psicológica e ao vínculo intersubjectivo criado com base nas paixões, traços determinantes dos motivos voluntários e involuntários, intencionais e não intencionais, dos personagens e/ou autores inseridos na literatura epistolar. O outro nível concerne à difusão do medium literário, e ao modo como a mesma está depende inequivocamente da generalização de meios técnicos e, em igual medida, da criação, manutenção e evolução dos mecanismos de simpatia e identificação. São estes mecanismos que possibilitam a adesão a uma forma de observar 
o mundo articulada com as regras da ficção, permitindo a "suspensão da descrença" e o laço moral que vincula o leitor à situação particular e aos estados mentais de um personagem que se constitui como centro da acção. Esses dois níveis mostram como o percurso do sujeito da enunciação para o reconhecimento de si, modelo clássico do romance e da novela, está sempre dependente de uma síntese entre a suposta verdade do sujeito, a sua construção em acto, e os modos de articular linguisticamente a referência aqueles dois níveis tornando-os legíveis a um público. Aquela síntese é sempre provisória. Nas cartas de Mariana ela é feita e refeita na conjugação entre a opacidade dos correlatos orgânicos e a sua integração nas sequências (e expectativas) comunicativas, ambas participantes da sua individuação ${ }^{1}$.

As Lettres Portugaises permitem compreender como estes aspectos confluem na construção da paixão, em particular da paixão amorosa mostrando também de que modo a comunicação é responsável pela descoberta ou, melhor dizendo, pela criação de novas repercussões sociais para o vínculo entre os amantes até então sem relação óbvia ou directa com o firmar do parentesco.

Deve esclarecer-se de antemão que o amor, enquanto código comunicativo na base da semântica da intimidade, pertence aos meios de comunicação orientados mais pela vivencia subjectivamente enquadrada do que pelas possibilidades de acção como é o caso do dinheiro e do $\operatorname{poder}^{2}$. À imagem do que sucede nos media da arte e religião, não há no meio de comunicação amor um referente directo que sirva de base ao funcionamento do sistema respectivo, neste caso a intimidade, mas ocorrências com dependência de factores vivenciais, em especial da coordenação entre as vivências dos amantes. Além do seu inegável valor estético, as Lettres são importantes na medida em que nelas se aprofunda a vivência apaixonada, articulando discursivamente os

${ }^{1} \mathrm{O}$ desenvolvimento destes temas a partir da teoria da individuação multilinear da sociedade moderna pode ser encontrado em EdMundo BALSEMÃo PIRES „J'ai éprouvé que vous m'étiez moins cher que ma passion: paixão e identificação projectiva nas “"Lettres portugaises”", Revista Filosófica de Coimbra, 41 (2012), pp. 33-80, esp. pp. 45 e ss.

${ }^{2}$ Niklas Luhmann, Liebe - eine Übung, Frankfurt a.M.: Suhrkamp, 2008, pp. 12 e ss. 
correlatos orgânico e imaginário, ao passo que denunciam a quebra do retorno essencial para retroalimentar a paixão.

As Lettres apresentam o modo como a paixão será por assim dizer magnificada não apenas em virtude da situação particular do narrador, inserido na própria sequência descrita, coincidência problemática de observador e observado, mas também pelo género de escrita. $\mathrm{O}$ autor das Lettres não se terá limitado a projectar no seu "autor implícito", a figura empírica e histórica de Mariana Alcoforado (1640-1723), temas que julgou apelativos para o público ávido dos encantos da escrita feminina, mas também jogou com as especificidades do medium. Daí decorre a verosimilhança reconhecida às cinco cartas, pois nelas é legítimo entrever a autonomização da novela relativamente às categorias empíricas (o mimetismo da experiência e a vertente "exterior" da biografia), bem como a correspondência a modelos pré-estabelecidos de harmonia ética (conforme ocorre nos épicos e na literatura amorosa predominante no mundo medieval) ${ }^{3}$, assentando na criação de um domínio ficcional com regras literárias que permitem trabalhar aqueles conteúdos, em especial pela observação da coordenação entre o tempo psíquico e o social.

Tal como no romance nascente, também o romance epistolar está envolto num mau infinito fruto da ausência de uma plenitude assegurada à partida. Aqui é ao signatário (implícito ou real) da carta que compete criar o guião. E ainda que os costumes e os modos convencionados de interacção não comportem a vivência e narração do personagem que busca o reconhecimento, a articulação narrativa não decorre de modo abstracto. A ancoragem empírica da acção é o garante da formação efectiva do carácter, de um estreito laço unindo a vivência e a escrita em acto, naquela que pode ser descrita como "a passagem da necessidade de nomear o mundo para a necessidade de se nomear a si mesmo"4.

${ }^{3}$ Cf. e.g. Pedro Catedra, Amor y Pedagogía en la Edad Media (Estudios de doctrina amorosa y prática literaria), Salamanca, Universidad de Salamanca, pp. 11-56.

${ }^{4}$ J Ay Bernstein, The Philosophy of the Novel. Lukács, Marxism \& the Dialectics of Form, Minneapolis, University of Minnesota Press, 1984, p. 151. 


\section{Problematização contemporânea da significação e alcance das Lettres}

As Lettres Portugaises são um marco fundamental na literatura epistolar ao integrar, de modo inédito, a paixão amorosa como tema privilegiado de comunicação sempre entre o real e o fictício, o privado e o público. As sucessivas cartas de Soror Mariana não suprimir a distância ou a ausência, mas favorecem o profundo conhecimento do tipo e intensidade da paixão, esclarecendo sua origem, efeitos orgânicos, correlato imaginativo e expectativas sociais associadas. A paixão é apresentada de acordo com um novo modelo fisiológico que solicitará a fixação de fórmulas retóricas eficazes e universalizáveis do ponto de vista simbólico, capazes de significar um novo enquadramento dos afectos assente não numa tipificação estanque, mas na particularidade do temperamento individual e das circunstâncias e sequências biográficas. Desse modo, a articulação da paixão na narrativa das Cartas da religiosa portuguesa, fruto também das especificidades do medium epistolar, mais que uma transposição da semântica do amour-passion nascente, é uma das suas maiores contribuintes. A sua inovação consiste na exposição do movimento das emoções numa alternância entre a observação e avaliação das paixões que é transposta para expressão escrita, pretensamente imediata ${ }^{5}$.

Adoptando expressões de Deloffre e Rougeot ${ }^{6}$, Jean-Michel Pelous notou que a descoberta do autor real das cartas, ao invés de pôr termo às questões levantadas pelas Lettres, veio abrir novos problemas interpretativos pois: "[p]asser brusquement d'un 'miracle d'amour' à un 'miracle de culture' ne va pas sans difficultés: c'est le statut d'une forme romanesque en partie nouvelle qu'il importe de préciser"7.

${ }^{5}$ RAYMOND LEBÈGUE foi um dos primeiros autores a saliantar a importância dessa inovação, cf. Id., "La sensibilité dans les lettres d'amour au XVII" siècle", Cahiers de l'Association internationale des études francaises, 11 (1959), p. 77-85.

${ }^{6}$ Frédéric Deloffre e Jacques Rougeot, "Les Lettres Portugaises, miracle d'amour ou miracle de culture", Cahiers de l'Association internationale des études françaises, 20 (1968), pp. 19-37.

${ }^{7}$ Jean-Michel Pelous, "Une Héroïne romanesque entre le naturel et la rhétorique: Le Langage des passions dans les Lettres portugaises", Revue d'Histoire Littéraire de la France, 77 (1977), pp. 554-563, p. 554. 
Seguindo a senda aberta pela descoberta do autor epistolar das Lettres, pôde equacionar-se à luz dos dados biográficos disponíveis e dos círculos que frequentava Gabriel-Joseph de Lavergne, comte de Guilleragues, corresponderia aos anseios literários de sua protectora Henriette d'Angleterre, apreciadora do género e interessada na escrita apaixonada ${ }^{8}$. Esse desígnio é conseguido em parte seguindo o exemplo de trocas epistolares já presentes em obras italianas e espanholas, entre outras, da atriz Isabella Andréini, recolhidas e traduzidas em 1642 por François de Grenaille ${ }^{9}$. Mas seria insuficiente adaptar os tópicos da antiga retórica e o modelo ético-amoroso subjacente. A composição das cinco cartas responde a um anseio que se agudizava entre os círculos letrados desde as primeiras coletâneas do género associado à expressão da diferença feminina. Daí procedem a recolha e criação de relatos fiéis da agitação emocional feminina que perdurarão até ao final do século seguinte ${ }^{10}$, constituindo o molde da tradução de cartas de Heloísa a Abelardo para o francês ${ }^{11}$. Ao mesmo tempo o moralismo e racionalidade dominante na literatura epistolar "regular", com clara correspondência nas doutrinas neo-estóicas, são denunciados e o amor galante e cortês passa a cair na caricatura de uma encenação redutível ao interesse económico ou ao prazer ${ }^{12}$.

As palavras de Claude Joseph Dorat cerca de um século após a publicação das Lettres Portuguaises, são demonstrativas da subsistência na literatura de cartas de dois desígnios de difícil harmonização: o conhecimento da sensibilidade e dos afectos e a formação pedagógica, mas também a sua vocação terapêutica, sendo que o género epistolar

${ }^{8}$ Cf. JacQues Chupeau, Vanel et l'énigme des Lettres portugaises, Revue d'histoire littéraire de la France, 2 (1968), pp. 221-228.

${ }^{9}$ Ver o seu Nouveau recueil de lettres des Dames, tant anciennes que modernes, 2 Tomes, Paris, Toussaingt Quinet, 1642. Sobre esta possível influência na composição das Lettres, cf. JeAn-Michel Pelous, "A propos de l'interprétation de la première Lettre portugaise”, R.H.L.F., 2 (1972), pp. 202-208.

${ }^{10} \mathrm{Cf}$. Henri Coulet, "Le style imitatif dans le roman épistolaire français des siècles classiques", Revue d'Histoire littéraire de la France, 1 (1985), pp. 3-17.

${ }^{11}$ Cf. Deloffre e Rougeot, "Les Lettres Portugaises...”, pp. 25-28.

${ }^{12}$ Para um esquema abrangente da evolução da função social e literária das cartas ver: Françoise Simonet-Tenant, "Aperçu historique de l'écriture épistolaire: du social à l'intime”, Le français aujourd'hui, 147 (2004), pp. 35-42. As Lettres se situam já na fase posterior à da eloquência: "passage d'une sociabilité savante liée à la lettre érudite, à une sociabilité mondaine" Ibid, p. 37. 
"donne à l'âme toutes les émotions dont elle est susceptible, peint tour à tour l'abattement de la douleur ou l'ivresse du plaisir" ${ }^{13}$. Noutra obra referiu ainda que " je vois rien de si naturel que de supposer un Personnage intéressant, agité de quelque passion violente, qui, par le moyen d'une lettre, soulage les ennuis de l'absence (...). Une lettre, de tous les genres d'écrire, est le plus vrai, le plus rapproché de l'entretien ordinaire, et le plus propre surtout au développement de la sensibilité"14.

Ciente de que o signatário de uma carta não estava necessariamente subordinado ao género epistolar ou condicionado pelos efeitos estéticos que a obra literária visa obter junto da audiência idealizada ${ }^{15}$, Roger Duchêne, defendeu que as Lettres se inserem numa transformação capital da literatura epistolar que até meados do século XVII dispensara a necessidade de individualizar o destinatário. Nesse sentido afirma: "[i] 1 n'y a pas commerce de lettres entre tel homme et telle femme, mais échange épistolaire entre représentants des sexes masculin et féminin. Fictives ou, à en croire les auteurs, réellement échangées (mais profondément remaniées), ces lettres appartiennent à la tradition littéraire, à laquelle la lettre galante, née des salons, s'est progressivement intégrée" 16 . Essa nova tradição tem na sua génese as Lettres cujo endereçamento tem como dínamo as particularidades do amado, o mesmo é

${ }^{13}$ Claude Dorat, Lettres en vers, ou épîtres héroiques et amoureuses, Paris, Sébastien Jorry, 1766, p. I. [Tal como nas citações subsequentes optamos por adaptar a escrita original à ortografia do francês contemporâneo].

${ }^{14}$ Claude Dorat (ed.), Collection d'Hérö̈des et Pièces Fugitives de Dorat, Colardeau, Pezay, Blun de Sain-More, \& autres, tome I, Francfort et Leipsig, 1771, pp. 134-135.

15 "Pour clarifier les idées, nous appellerons épistolier celui qui ne tient pas compte de l'existence du public et auteur épistolaire celui qui, au contraire, se soucie plus d'un public éventuel que de celui à qui il est censé écrire" Id., "Réalité Vécue et Réussite Littéraire: le Statut Particulier de la Lettre" Revue d'Histoire littéraire de la France, 2 (1971), pp. 177-194, p. 177.

${ }^{16}$ Roger DuchêNe, “Réalité Vécue...”, p. 180. Cf. tb, Robert Folger, ,Geschlechterentwürfe und die (Ent-)Pluralisierung des Subjekts im frühneuzeitlichen Medienwandel (Spanien 15. und 16. Jh.) “ in Judith Klinger \& Susanne Thiemann (eds.), Geschlechtervariationen, Gender-Konzepte im Übergang zur Neuzeit, Potsdam, Universitätsverlag Potsdam, 2006, p. 131-156. 
dizer o modo como ele afectou os sentidos e as faculdades de espírito de Mariana ${ }^{17}$.

Ao mesmo tempo que a escrita apaixonada, literária ou privada, passa a requerer a reflexão e o endereçamento comunicativo individualizante, surge a sensibilidade para a distinção, herdada da antiguidade, entre as paixões da alma intelectivas, pautadas pelo domínio intencional e pela clareza e as paixões conotadas com o erotismo e a concupiscência, invariavelmente tomadas como ameaçadoras da ordem social. A desordem da escrita é correlativa da desordem da alma, expressa uma intensidade e qualidade da emoção e sentimento que permitem afirmar "que la lettre amoureuse est à la lettre galante ce que l'élégie est au madrigal", i.e. o seu autor não procura transmitir uma relação orientada pela regularidade do trato das "preciosas", conforme à ordem racional dos enlaces previstos, mas pela gramática e cadência da nova linguagem do coração ${ }^{18}$.

A grande maioria dos intérpretes da obra convictos da sua origem ficcional sustenta que Mariana, o seu autor implícito, se lamenta desde o início do cavaleiro que não responde às missivas até se dar conta de que este a abandonou ${ }^{19}$. Podemos qualificar essa interpretação como espontânea, além de parecer mais intuitiva, ela aproxima as Lettres de um modelo canónico da escrita feminina ${ }^{20}$. Tal leitura insere a obra na longa tradição das herodíades, a qual remonta ao episódio do aban-

\footnotetext{
${ }^{17}$ Pese embora uma tradição interpretativa distinta cujo maior representante é W. Leiner, cf. infra.

${ }^{18}$ Cf. JacQues Chupeau, "Remarques sur la genèse des 'Lettres portugaises", Revue d'Histoire littéraire de la France, $3 / 4$ (1969), pp. 508-513, 508 e ss. O autor baseia-se na Lettre IX do Recueil de quelques Lettres ou Relations galantes de Mlle. Desjardins, onde a escritora defende um meio termo entre a frieza da paixão incapaz de irromper na indiferença dos leitores e a escrita desordenada com seu ritmos irregulares, tão apreciada pelos enamorados (Paris, Claude Barbin, 1668. Lettre IX, “A Amsterdam le 25 May” [1667], pp. 79-80).

${ }^{19}$ Por diversas vezes se equacionou que o destinatário das Cartas seria Noël Bouton, Marquis de Chamilly, feito cavaleiro por ocasião da Guerra da Restauração.

${ }^{20}$ Marianne assume uma posição ilocutória tradicional na qual, como afirma ROLAND BARTHES (sub verbo “ausência”): “[c]'est la Femme qui donne forme à l'absence, en élabore la fiction, car elle en a le temps; elle tisse et elle chante ; les Fileuses, les Chansons de toile disent à la fois l'immobilité (par le ronron du Rouet) et l'absence (au loin, des rythmes de voyage, houles marines, chevauchées)" Id., Fragments d'un discours amoureux, Paris, Seuil, 1977, p. 20.
} 
dono de Dido na Eneida, mas cujas variantes e expansão se devem a Ovídio $^{21}$. Dessa tradição literária mantém-se a ideia de que a mulher, por intermédio da proficiência na escrita elegíaca, o servitium amoris poderá atear em seu amado o fogo da paixão ${ }^{22}$. Mas nas Lettres o abandono da mulher não se fica a dever a motivos eminentes, como a defesa da comunidade, ele é de acordo com o lamento de Mariana, resultante da vanidade e da mediocridade da paixão do cavaleiro.

Contestando esse modelo, Wolfgang Leiner assinalou os paralelismos entre a linguagem presente nas Cartas e a autobiografia dos místicos em voga desde o século XVI e propôs que logo na primeira frase das Cartas -"Considère mon amour, jusqu'à quel excès tu as manqué de prévoyance"- Mariana se endereça, não ao cavaleiro, mas à sua própria paixão. Leiner notou a alternância entre o tratamento na segunda pessoa (o "tutois") e o distanciado e respeitoso, sustentando que as Lettres são na verdade um diálogo, terno e íntimo, entre Mariana e sua paixão, diálogo que de acordo com aquele autor vai sendo pontuado pelo tom recriminatório e distanciado relativamente ao amante alvo de invectivas ao longo das cartas ${ }^{23}$.

Desse modo, o que disse L. Spitzer acerca da quarta carta pode ser aplicado também ao conjunto: "elle n'écrit plus pour un destinataire, elle se contente d'écrire, de s'écrire" 24 . Em certa medida isso significa que o cavaleiro não é senão um detalhe, um títere necessário ao desenvolvimento da escrita e do fluxo do pensamento. Se assim for, o erro grassa desde a edição original de Claude Barbin ${ }^{25}$. Também neste caso, "[q]ue les lettres aient été considérées comme authentiques par

${ }^{21}$ Ver a este propósito o trabalho de Suzanne C. Hagedorn, Abandoned women: rewriting the classics in Dante, Boccaccio, Ann Arbor, The University of Michigan Press, 2004.

22 Tome-se como exemplo o clamor de Briseida a Aquiles, cf. Ovideo, Heroides and Amores, London, William Heinemann, 1914, pp. 33-43; SARA LindHEIM, Mail and Female: Epistolary Narrative and Desire in Ovid's Heroides, Ann Arbor, University of Michigan Press, 2003, pp. 53-62.

${ }^{23}$ WOLFGANG LeINER, "Vers une nouvelle interprétation des Lettes portugaises: Marianne entre son amour et son amant", Romanische Forschungen, 77 (1965), pp. 64-74, esp. 70 e ss.

${ }^{24}$ LeO SPITZER, "Les lettres portugaises"”, Romanische Forschungen, 65 (1953), pp. 94-135, 105.

${ }^{25}$ A dimensão "peritextual" da edição de Claude BARBIn, em particular o seu "Avis au Lecteur", parece contrariar a tese de Leiner, ainda que seja possível que 
les uns ou comme fictives par les autres importe peu, puisque les uns et les autres voyaient en elles une ouvre obéissant aux règles du genre épistolaire"26.

$\mathrm{Ph}$. Hourcade chamou a atenção para o facto de que tal interpretação das Lettres tem antecedentes na leitura de Du Plaisir para quem a apóstrofe inicial " 'mon amour' est une invocation adressée au sentiment personnifié de celle qui écrit" sendo que "contrairement aux autres genres en prose, la lettre amoureuse permet, par définition, nombre de libertés avec la langue française telle que l'ont voulue les théoriciens du siècle, aussi bien qu'avec la morale. L'ordre syntaxique peut y être bousculé, l'équilibre des périodes rompu, la 'modestie' de l'expression troublée par des écarts poétiques : métaphores, hyperboles ou apostrophe" 27.

É certo que além do modo invocativo, o progressivo e doloroso afastamento da paixão relativamente ao sensório permitem a leitura das Lettres na proximidade dos exercícios místicos muito em voga no Siglo de $\mathrm{Oro}^{28}$. Mas a universalização da sensibilidade aos temas do amor apaixonado depende em grande medida do vínculo estabelecido entre uma nova concepção e juízo das paixões e a sua articulação narrativa na primeira pessoa.

Partindo da tese proposta por Leiner de uma duplicidade da paixão narrada por Mariana, uma paixão transitiva e outra intransitiva, é possível detectar na construção da vivência apaixonada da freira não só a sequência das afecções subsequentes à uma quebra da autoestima, mas também uma observação da paixão por si mesma como passível de valor emocional e judicativo e capacidade de reorientação face ao seu objecto ou fantasia, i.e. capaz de se curar.

aquele Editor desconhecesse as peculiaridades da adaptação ao francês das cartas autênticas de uma religiosa portuguesa.

${ }^{26}$ LEINER, "Vers une nouvelle...", 72-3.

${ }^{27}$ Philipe Hourcade, "Du Plaisir et l'apostrophe initiale de la première Lettre portugaise", Revue d'Histoire littéraire de la France, 6 (1973), pp. 1043-1045. Cf. Du PLAISIR, Sentiments sur les Lettres et sur l'Histoire avec des scrupules sur le style (ed. critique Ph. Hourcade), Genève, Droz, 1975 [1683], p. 30-1.

${ }^{28}$ VolKer SchröDER, "Les méditations de Marianne: la matrice mystique des Lettres Portugaises" in R. Hodgson (ed.), La Femme au XVII siècle, Tübingen, Narr, 2002, pp. 283-299. 
A narração individual de Mariana, fruto das suas circunstâncias, regride para um encerramento e auto-referencialidade do fluxo da consciência que, aquém da articulação dos símbolos da relação exclusiva dos amantes, parece oscilar entre os extremos descritos para a condição melancólica. O itinerário que seguimos na secção seguinte permitirá reconhecer a exploração das emoções e sentimentos intensos associados ao vínculo entre os amantes, seu tipo de projecção e o processo de cura, ou pelo menos de libertação da fixação mnemónica e imaginativa. Por força da especificidade do seu objecto a literatura dedicada à melancolia amorosa integrou a análise fisiológica e a dimensão moral das paixões. Nesses tratados dedicados à perdição, aos anseios irrazoáveis e ao sofrimento relacionado com o amor encontramos várias afinidades com as Lettres $^{29}$. Essa conformidade com a via terapêutica não é meramente circunstancial, mas está indicada na concordância da obra com os termos a teoria fisiológica e moral das paixões da alma cartesiana e com a viragem semântica que a mesma anuncia. Ao mesmo tempo é notório que a obra está ainda dependente de um modelo curativo com ascendência nas considerações médicas e literárias tecidas em torno de um tipo muito particular de melancolia, apelidada de heróica ou erótica.

\section{A sensibilidade e as paixões melancólicas}

A causa, os sintomas e as vias para a libertação da paixão cujo decaimento nos é narrado por Mariana, haviam sido objecto de reflexões médicas sistemáticas em torno das paixões de tipo amoroso. Tais paixões distintas da devoção a Deus e da amicitia, formas castas de relação amorosa, eram consideradas patológicas em virtude da propensão do amor sensório para a degradação física, moral e espiritual do indivíduo. Nesta secção selecionamos alguns dos aspectos fulcrais dessas abordagens e atentamos na mutação envolvida na passagem do

${ }^{29}$ A leitura das Lettres como via terapêutica foi adoptada no feminismo contemporâneo por PegGy Kamuf, Fictions of Feminine Desire: Disclosures of Héloïse, Lincoln, University of Nebraska Press, 1982, 55-66. Mais recentemente, Pierre Zoberman regressou a este tema sem contudo o desenvolver na sua vertente médica, cf. Id. "Représentation de l'écrivain et identités sexuelles" Seventeenthcentury French Studies, 1 (2008), pp. 77-91, p. 84. 
contexto renascentista para a compreensão das paixões da alma de Descartes. Esta incursão procede das margens da Psiquiatria cultural e tem subjacente a questão de saber se é possível desvincular as patologias, em particular as que incidem sobre as faculdades mentais, dos preceitos científicos, religiosos e morais de uma determinada época histórica. Na melancolia essa impossibilidade foi notada logo pelos autores que como Robert Burton se dedicaram a compulsar o conjunto de observações e teorias, quantas vezes contraditórias, erigidas em torno desse mal-estar ao longo de diferentes épocas. Foi esse mesmo exercício que permitiu destacar aspectos da psicopatologia inacessíveis sob o foco da biomedicina.

\subsection{A compreensão do amor hereos e seus modelos curativos}

Ainda que pareça uma tese provocatória, a verdade é que muitos fenómenos patológicos, sobretudo relativos aos "desvios" que a medicina do século XIX considera terem causas e enquadramento eminentemente psíquicos, eram explicados na medicina pré-moderna como manifestações psíquicas de uma desordem somática ${ }^{30}$.

A concepção da patologia, em particular da melancolia, presente nos maiores representantes médicos das universidades medievais herda a recepção e conjugação entre a doutrina do pneuma aristotélico e do humoralismo hipocrático-galénico. É assim que até à renascença o temperamento individual, i.e. as predisposições da alma para a intelecção e para a acção, são consideradas em relação estrita com a compleição individual, entendida como resultado da distribuição e mistura dos 4 humores no organismo: sangue, bílis amarela, bílis negra e fleuma. Associados aos elementos constitutivos do cosmos, esses humores conjugam-se com a disposição dos astros no momento do nascimento, as estações do ano e a idade do indivíduo sendo impressos em certos traços fisiognomónicos ${ }^{31}$. Só por volta do século XI se inicia a organiza-

${ }^{30}$ Cf. JoAchim KüpPer, Das Schweigen der Veritas und die Worte des Dichters, Berlin, de Gruyter, 2002, esp. pp. 115-125.

${ }^{31}$ Até à renascença podemos ver a composição de um infindável palimpsesto infinito de associações alegóricas, por vezes contraditórias que permitem conceber o indivíduo como o centro íntimo de uma configuração cósmica. Esse reflexo da 
ção de modo sistemático de quatro temperamentos distintos de acordo com o predomínio dos humores: sanguíneo, colérico, melancólico e fleumático. Coube a Avicena distinguir o temperamento, o carácter e as patologias decorrentes dessas compleições naturais e as suas formas "artificiais" fruto de alterações nos fluídos resultantes de certas acções ou de determinados modos de vida ${ }^{32}$. Para o nosso propósito importará a sua ideia, sucessivamente glosada, de melancholia adusta ou incensa. De acordo com a maioria dos autores a produção desse tipo de melancolia pode afectar indivíduos sem compleição originalmente melancólica por vezes de forma permanente.

Foi na tradição da melancolische Traurigkeit, considerada condição mental específica daqueles que estão encerrados em organizações religiosas, que se tornou evidente a importância de factores relacionados com os hábitos de vida no abatimento de muitos religiosos que antes da clausura nunca haviam padecido de sintomas como a athumia e a acedia. Certas práticas monásticas eram postuladas como origem daquela degradação física e espiritual, nomeadamente o sedentarismo e a dieta condicionada pelo desgaste dos mais finos e leves espíritos animais no estudo e tributo religioso ${ }^{33}$. Nessa mesma tradição se vêm a formar correntes que tomavam o enfraquecimento do corpo e a vulnerabilidade da condição melancólica como vias privilegiadas de comunicação com o divino.

Mas um outro tipo de sofrimento começa a ser referido como origem da condição melancólica, relacionado com o amor que estimula os sentidos exteriores, cultivado pelos poetas e trovadores, denominado amor hereos.

A formação da designação amor hereos está longe de ter uma origem etimológica unívoca e parece decorrer da contaminação entre ter-

constituição corpórea do indivíduo no seu carácter foi compulsado na Iconologia (1593) de Cesare Ripa.

${ }^{32}$ Sobre este tema ver a clássica obra colectiva de RAYMOND KLIBANSKY, ERwin PANOFSKY e Fritz SAXL: Saturn and Melancholy: Studies in the History of Natural Philosophy, Religion, and Art, Nendeln, Kraus, 1979, pp. 86-90.

${ }^{33}$ Cf. Klibansky, Panofsky e Saxl, Saturn and Melancholy, pp. 75 e ss. Uma apresentação da história da melancolia religiosa que parte das exortações de São Crisóstomo a Stagirus, pode ser encontrada em Peter ToOHey, Melancholy, Love, and Time: Boundaries of the Self in Ancient Literature, University of Michigan, 2004, pp. 137-156. 
mos gregos, mormente eros, referindo o pathos e conhecimento sensório associado ao amor, e latinos remetendo tanto para herus, que indica o tributo amoroso a um senhor, como para heroici, virtude associada à nobreza como estrato mais propenso a este padecimento ${ }^{34}$. Em todo o caso ele está na origem de uma disfunção cuja abordagem remonta ao Viaticum de Constantinus Africanus, e à qual serão dedicados diversos tratados caracterizados por uma assinalável consistência não só na descrição da causa, do processo e sintomas, mas também dos procedimentos terapêuticos aproriados para lidar com essa forma de morbus. Patologia do desejo que Ficino no De amore caracterizou como desvio relativamente à forma contemplativa de amor, aquela em que verdadeiramente se encontra uma adequada correspondência entre a entrega e tributo do amante e o valor ontológico do amado.

É a partir dos finais do século XVI que emergem novos modelos relativos ao processo de enamoramento, suas consequências patológicas (semeiosis dos sintomas) e processo terapêutico. Os escritos dedicados a tal distúrbio aqui seguidos, visaram colmatar o desconhecimento das singularidades da melancolia erótica contraposta não só às outras formas clássicas de patologia, o Furor e a Mania, mas relativamente à própria melancolia lato sensu. Todo o tratado que Jacques Ferrand dedica à l'essence et guérison d'amour ou De la Mélancolie érotique (1610), tem por fito diferenciar essa "paixão do espírito" que considera dentre todas como a mais danosa. O mesmo pretendeu Robert Burton na terceira parte da Anatomy of Melancholy, ao distingui-la das suas formas religiosas.

Nesses compêndios é já notória a demarcação face aos modelos astrológicos e mágico-religiosos (que abundam por exemplo nas concepções amorosas e terapêuticas de Ficino), e a procura da causalidade da doença independentemente de dogmas inquestionados. Por outro lado, nos trabalhos desses representantes da literatura humanista verifica-se uma maior receptividade a temas morais o que contribui para o questionamento acutilante das teorias dos neo-galénicos. Contudo, ao

${ }^{34}$ Seguindo autores como Arnaldus de Villanova e Bernard de Gordon, JACQUES FERRAND subscreve esta mesma origem, cf. Id., De la maladie d'amour ou melancholie erotique. Discours curieux qui enseigne à cognoistre l'essence, les causes, les signes, \& les remedes de ce mal fantastique, Paris, Denis Moreau, 1623 , p. 15. 
identificarem resolutamente a paixão de tipo amoroso com o patológico são incapazes de analisar a dimensão relacional das paixões, em particular o modo como nelas se desenvolve um tipo de vínculo que será explicado a partir da simpatia.

Além das prescrições terapêuticas importa reter duas teses maiores articuladas nestes tratados: 1) a ideia de que as paixões mais violentas, em particular as originadas nos sentidos, alteram o equilíbrio dos humores e degradam as faculdades mentais e 2) a defesa de que essa alteração na origem dos distúrbios decorre da cessação abrupta da retribuição do amor e/ou da interdição de contacto com o amado.

Toda a inquirição filológica que encontramos na obra de Ferrand está ao serviço de uma análise médica de pendor fisicalista. Ferrand defendia acerrimante a especificidade e diferenciação da observação médica: "il nous est permis de subroger les propriétés, qui ne sont les mêmes en toutes les sciences: au moyen de quoi le Physicien définit autrement que le Métaphysicien, le Médecin autrement que le Jurisconsulte, \& l'Orateur ne donnera pas la définition semblable à celle du Poète" 35 .

Ferrand percorre várias obras poéticas em que os distúrbios da paixão amorosa conduziram à morte provocada, ora pela extrema alegria [joye extreme], ora pela vergonha [honte] ${ }^{36}$. Ela é considerada como " passion de l'âme introduite par les sens pour satisfaire au désir"37, desejo baseado na "esperança de volúpia" que se torna desregulado pela impossibilidade de aceder ao objecto amado. Tal concepção está sempre a par da ideia mais geral da transitoriedade do sensível por oposição ao espiritual.

Nestes tratados, em consonância com a importância assumida pela dinâmica do binómio "ver - ser visto" nos romances pastorais, o olhar é a fonte de um contágio, sendo os olhos as "fenêtres par lesquelles l'Amour entre dans nous pour attaquer le cerveau" "38. A influência de Ficino e de um modelo de eros platónico é aqui notório, sendo que tam-

\footnotetext{
${ }^{35}$ Ferrand, De la maladie d'amour..., "aux lecteurs".

${ }^{36}$ FERrAnd, De la maladie d'amour..., p. 6.

${ }^{37}$ Ferrand, De la maladie d'amour..., p. 23.

${ }^{38}$ Ferrand, De la maladie d'amour..., p. 16-21.
} 
bém Burton entende o enamoramento a partir do modelo de contágio, transmissão dos espíritos animais pelo olhar ${ }^{39}$.

Ferrand, tal como Burton depois de si, adapta o modelo da melancholia adusta vigente nos autores medievais, para explicar como podem as "causas externas" do amor erótico conduzir à melancolia amorosa propriamente dita. Curiosamente, os padecimentos do amor de tipo erótico são quase exclusivos dos indivíduos de compleição sanguínea exclusiva do fulgor da juventude, o que fica a dever-se à maior propensão destes à união amorosa, a qual ocasiona uma combustão nefasta do sangue no cérebro do amante. A idealização e a intensa fixação da imagem do amado agita a imaginação e a memória originando, na dependência do coração, uma maior emissão de calor e aumento de pulsação. $\mathrm{O}$ dispêndio desses fluidos no cérebro tem um aumento exponencial aquando do desaparecimento ou abandono do amado e do subsequente complexo de reacções emocionais. É nesse processo que tem lugar a produção de uma forma artificial de melancolia com origem na intensa combustão do sangue que aflui ao cérebro ${ }^{40}$. Essa alteração dos fluidos orgânicos, contribuinte para uma maior torpidez do sangue, provoca um arrefecimento e secura súbitos do cérebro, alterações danosas para as suas partes imaginativa e rememorativa ${ }^{41}$.

Apesar de ter o coração como órgão central na sua etiologia, esta forma de melancolia incide primeiramente no cérebro, subscrevendo a doutrina exposta no De Locis Affecti de Galeno ${ }^{42}$. Trata-se de uma doença que afecta as partes da alma de modo transitório. Contudo os autores concordam, se não for tratada convenientemente, ela pode atingir não só certas funções cerebrais mas impedir "l'âme immortelle l'exercice de ses facultés \& vertus" ${ }^{43}$. Os seus danos podem evoluir para a senilidade ou para um quadro maníaco culminando em formas

${ }^{39}$ Apresentando mesmo a ideia de que o amado emite raios, provenientes do coração que contém o seu fantasma e põem em movimento os espíritos daquele que olha, cf. Robert Burton, The Anatomy of Melancholy... Philadelphia, E. Claxton \& company, 1883, 3.2.2.2., pp. 468-470.

${ }^{40}$ Ferrand, De la maladie d'amour..., pp. 54 e ss.

41 "Both imagination and reason are misaffected, because of his corrupt judgement, and continual meditation of that which he desires" Burton, The Anatomy of Melancholy..., 3.2.1.2, p. 453.

${ }^{42}$ Cf. Ferrand, De la maladie d'amour..., pp. 60-65.

${ }^{43}$ Ferrand, De la maladie d'amour..., p. 20. 
extremas de agressão a um si-mesmo desprovido de valor (suicídio), ao outro que recusa entregar-se ou àquele(s) que se opõe(m) ao enlace (homicídio) ${ }^{44}$.

Os autores referem sintomas complexos que têm como causa eficiente o corpo (sangue e espíritos animais) afectando as partes da alma: a fixação no objecto (que penetrou os órgãos sensoriais e atingiu o sentido interno), o distúrbio e alteração do sentido perceptivo acompanhados de profusão verbal e também a alienação e divisão do sujeito ao nível mental ${ }^{45}$. Além disso, mencionam sinais exteriores intuitivamente associados ao desgosto ou à nostalgia amorosa como a busca da solidão, o olhar vazio, a palidez e formas de anorexia e bulimia, insónia, sintomas acompanhados de febre lenta ${ }^{46}$.

Na sua abordagem da febre que acompanha os "hiéroglyphes de douleur \& peine mortelle" do amor erótico, Ferrand sublinha que ainda dentre os sanguíneos "les femmes sont plus frileusement \& plus souvent travaillées de ces maux" ${ }^{47}$, e irá proceder a uma distinção, bastante influente nas concepções psiquiátricas dos séculos seguintes, entre o furor uterinus e a satyriasis. Trata-se de formas específicas de perturbações, afectando respectivamente homens e mulheres, com origem nos vapores originados no baixo-ventre e na zona abdominal: a histeria e a hipocondria ${ }^{48}$.

No tocante à terapêutica da melancolia amorosa, Ferrand questionou a abordagem tradicional que recomenda a consumação sexual como cura mais adequada, prescrevendo remédios, bem como regimes dietéticos e admitindo em casos extremos intervenção cirúrgica ${ }^{49}$. O seu

${ }^{44}$ Cf. Burton, The Anatomy of Melancholy..., 3.2.4.1., pp. 523-525.

${ }^{45}$ Cf. Burton, The Anatomy of Melancholy..., 3.2.3.1, pp. 496-523.

${ }^{46} \mathrm{Cf}$. Ferrand, De la maladie d'amour...,pp. 84 e ss. Já a propósito das lágrimas, FERRAND nota que as mesmas estão por vezes sujeitas a controlo voluntário sendo frequentes como recurso que permite a representação da dor, cf. FERRAND, De la maladie d'amour..., p. 102.

${ }^{47}$ Ferrand, De la maladie d'amour..., pp. 4 e 9.

${ }^{48}$ Cf. Ferrand, De la maladie d'amour..., pp. 75 e ss.

${ }^{49}$ Os métodos de cura da melancolia amorosa estavam muito difundidos e incluíam práticas como banhos e purgas, aplicadas noutros males. Contudo, Ferrand mostra-se reticente relativamente à intervenção cirúrgica que, para a maioria das compleições, passava por retirar sangue da veia hepática do braço direito, cf. FERRAND, De la maladie d'amour...p. 248. 
alinhamento com os preceitos religiosos e o moralismo época é legível nas suas recomendações profiláticas incluindo instruções relativas ao domínio das paixões e da concupiscência. Admite no entanto que a cura completa só seria possível por via da união ou, se esse for o caso, com a restituição do $\operatorname{amado}^{50}$.

Já em Burton encontramos uma observação crítica dos costumes de matrimónio, que aponta como origem de distúrbios patológicos. Além disso Burton considerará, contrariamente a Ferrand, o valor da poesia como bálsamo para o sofrimento amoroso, reavivando assim um tema clássico da poesia de Lucrécio $^{51}$.

Vemos que estes tratados permitem aceder a muitas das especificidades da paixão de amor que viu o seu curso "natural" interrompido. Alguns aspectos da sintomatologia do amor hereos degenerando em melancolia erótica, são concordantes com as cinco cartas de Mariana. Nas Lettres encontramos precisamente uma jovem inexperiente nos assuntos mundanos, que tem o primeiro contacto com o objecto de desejo pelo esgar através da famosa janela de Mértola. Esses indicadores biográficos de que dispomos são inequívocos quanto à juventude de Mariana, o que indicia um temperamento sanguíneo (de acordo com a divisão clássica das idades sensivelmente até aos 30 anos) inerente à juventude, justamente aquele que é referido como propenso às paixões de tipo erótico ou amoroso. $\mathrm{O}$ processo de enamoramento patente nas Lettres é também descrito como a incubação de uma doença que começa nos sentidos e penetra a alma, afectando a faculdade imaginativa e rememorativa, evoluindo para o total domínio da vida psíquica. As consequências da não correspondência do cavaleiro incluem o desencanto com o mundo exterior e a recriminação de si mesmo, ambas expressas de modo loquaz.

${ }^{50}$ Cf. Ferrand, De la maladie d'amour..., pp. 207-210.

${ }^{51}$ Desde o prefácio à terceira partição da Anatomy que se pode assistir à sucessão de citações de trechos poéticos da antiguidade que não se limita a uma função terapêutica e ilustrativa, mas parecem lançar um convite à fruição estética na origem da patologia. 


\subsection{Redescrição das paixões melancólicas na Psicologia moral cartesiana}

Nas Lettres encontramos uma inegável concordância com os sintomas exteriores da melancolia erótica, mas sobretudo com o modelo psicossomático que permite explicar a origem e especificidades dos trânsitos da alegria à tristeza e desespero, acompanhados de agressividade e vergonha. Não obstante, a terminologia aplicada aos movimentos emocionais e sentimentos que acompanham as tribulações de Mariana não assentam já nas sobrevivências da teoria humoral, mas no modelo da iatromecânica e da doutrina corpuscular, cujo grande representante é Descartes $^{52}$. É a essa transição terminológica e semântica que devemos prestar atenção.

Em contraposição ao que ocorria na fisiologia antiga, onde a paixão era identificável com uma configuração estável mediando corpo e alma, a partir do Renascimento, diversos autores, passam a apresentá-la como disposição que sujeita a alma a um movimento que a perturba ${ }^{53}$. Dentro desse esquema geral, Descartes proporá que tal como o corpo humano também o psiquismo pode ser descrito como movimento. Na proximidade com aquele que será o esquema de Hobbes e sua explicação das paixões como moção interna, as "paixões da alma" resultam do movi-

${ }^{52}$ A teoria fisiológica de Descartes está dependente em grande medida dos avanços na compreensão do sistema circulatório possível por intermédio de um método incompatível com a oposição resolutio-compositio, metodologia que suportara os tratados médicos dos Galénicos medievais e que começa a ser revista nas observações do De Motu Cordis de William Harvey. Para compreender o modo como Mecanicismo longe de a suprimir adapta a antiga teoria dos fluídos, cf.: Bernd Steinebrunner, Die Entzauberung der Krankheit. Vom Theos zum Anthropos - Über die alteuropäische Genesis moderner Medizin nach der Systemtheorie Niklas Luhmanns, Frankfurt a.M., 1987, pp. 322-337.

${ }^{53}$ Como o atesta Antoine Furetière no seu Dictionnaire Universel de 1690, antes da acepção religiosa da fisiologia medieval e do discurso filosófico remete para a concepção mecanicista de movimento: "[o]n peut dire que toutes les passions par lesquelles l'âme se porte à quelque chose, comme l'amour, ou l'ambition, sont plûtot de véritables actions, que des passions: \& qu'au contraire tous ces mouvements par lesquels l'âme se trouve interrompuë dans son actions, sont de véritables passions; comme la tristesse" cf. A. FuRETIÈRE, Dictionnaire universel, contenant généralement tous les mots françois tant vieux que modernes et les termes des sciences et des arts, 2 e édition revue, corrigée et augmentée, La Haye/Rotterdam, 1702 , p. 667. 
mento dos espíritos sobre a percepção. A divergência relativamente às explicações materialistas advém do dualismo ontológico, se bem que nos seus últimos escritos dedicados à vida emocional, a cisão entre o corpo e a alma esteja bastante mitigada, fruto da sua contínua comunicação e interdependência, ambas sustentadas na glândula pineal como interface entre as substâncias no ser humano ${ }^{54}$.

Nos escritos em que se devotou à compreensão das diferentes paixões, conjugando a fisiologia das emoções com a Psicologia moral, Descartes revela uma grande atenção ao valor psíquico e comunicativo da paixão, isto apesar de declarar que a sua abordagem está confinada ao seu conhecimento médico ${ }^{55}$. Remontando a 1643, a correspondência com a Princesa Elizabeth é em grande parte movida pelas dificuldades de conciliar o dualismo das Meditações com a vivência quotidiana, em especial com a corporeidade, mas também com a cura das emoções a que medicina ordinária não dá resposta ${ }^{56}$.

Descartes adapta o esquema galénico e sua divisão entre vegetativo, o sensitivo, o cognitivo e o intelectivo a uma leitura mecanicista que reconhece a especificidade dos "movimentos" do corpo e dos pensamentos da alma. Grande parte dos movimentos do corpo assenta num automatismo inato que permite, pela conexão entre o cérebro e os diferentes órgãos, a gestão da temperatura e dos movimentos musculares diversos activados pela circulação de sangue e mobilidade dos espíritos animais. Outros asseguram por exemplo a unificação das percepções tornando possível que a imagem impressa nos olhos surja à representação como una, por acção da glândula situada no centro do cérebro. Logo no artigo XII apresenta Descartes o modo como os objectos actuam sobre os órgãos dos sentidos sendo "comunicados" por via mus-

${ }^{54}$ Cf. Deborah J. Brown, Descartes and the Passionate Mind, Cambridge, Cambridge University Press, 2006, pp. 141 e ss.

${ }^{55}$ Como pode ler-se em carta de 14 de Agosto de 1649, provavelmente endereçada ao abade Picot, Cf. René Descartes, Les Passions de L'Âme in Id. Euvres (ed. C. Adam e P. Tannery), 11 vols., Paris: Léopold Cerf, 1910 [AT], vol 11, p. 326.

${ }^{56} \mathrm{Cf}$. carta de Elizabeth endereçada a Descartes, de 24 de Maio de 1645, AT IV, pp. 207 e ss.

Em causa está a diferença entre as especificidades do corpo representado (e dissecado) e o corpo vivido bem como as intersecções de ambos nas paixões como mostrou João M. André, Pensamento e Afectividade. Sobre a paixão da razão e as razões das paixões, Coimbra, Quarteto editora, 1999, pp. 19-37. 
cular e sanguínea ao cérebro ${ }^{57}$. Além da sua insubordinação à vontade, a especificidade das "paixões da alma" decorre do que podemos qualificar como capacidade de conservar certos efeitos dessas afecções na alma e da subsequente formação de padrões dos movimentos do corpo e do pensamento. Descartes concebe um mecanismo de constante re-entrada das percepções (exteriores e corpóreas) na alma e a retroacção das "emoções internas" (paixões da alma em sentido estrito) no corpo.

Mesmo as mais primitivas paixões da alma não podem ser tomadas como imediatas e reactivas, estando sempre dependentes de uma disposição do sujeito que leva a associar ao movimento uma determinada ideia. Isso significa que só faz sentido falar de "paixão da alma" entendendo-a como movimento que além de afectar os sentidos externo e interno se inscreve na memória. Mas essa memória bem como as associações que alberga não são estanques mas estão abertas à aprendizagem, na dependência das faculdades da imaginação, do entendimento e da vontade. As percepções, emoções e sentimentos experimentados nessas paixões têm repercussões orgânicas resultando em sinais por vezes involuntários e indisfarçáveis outras passíveis de controlo e expressividade calculada. Descartes sublinha a loquacidade que esses sinais podem assumir à margem da comunicação verbal ${ }^{58}$.

Muitas das ideias que atravessam a correspondência de Descartes com Elizabeth e Chanut, mas também as Passions de L'âme, seguem o antigo binómio entre o amor espiritual e o sensível, em especial a identificação da paixão terrena com a volúpia e a descrição dos seus efeitos patológicos.

Descartes seguiu a tradição estóica segundo a qual a paixão é potencialmente perniciosa não só epistémica mas também moralmente e deve ser direcionada pela razão. É em plena leitura conjunta do $D e$ Vita Beata que, na correspondência com Elizabeth, Descartes avança com a definição de paixão da alma contrapondo-a à acção governada pelo entendimento e vontade: "toutes les pensées qui sont (...) excitées en l'âme sans le secours de sa volonté" ${ }^{59}$. Logo de seguida, tem o cui-

${ }^{57}$ Assim se compreende que: "ce ne sont pas immédiatement les mouvements que si font en l'œil, mais ceux que se font dans le cerveau que représentent a l'ame ces objects", Descartes, Les Passions de L'Âme, I, art. 13, p. 338.

${ }^{58}$ Cf. Les Passions de L'Âme, AT XI, II, arts. 112-136, 411 e ss.

${ }^{59}$ Carta a Elizabeth de 6 de Outubro de 1645, AT IV, p. 310. 
dado de advertir, demarcando-se, a exemplo do que ocorrera nas cartas precedentes, das crenças religiosas e astrológicas como guia da análise médica e filosófica, que as paixões da alma não radicam na constituição inata nem no equilíbrio dos humores, mas no movimento dos espíritos proveniente do sentido interior ou exterior do indivíduo. Esses "trânsitos", esclarecerá em seu tratado sobre as paixões, vão-se fortificando nas associações mentais e sua retroacção no sangue e nos espíritos, tornando inviável uma correcção directa da paixão, especialmente no caso das mais violentas ${ }^{60}$. Isso mesmo é afirmado por Descartes logo no final da primeira parte das Paixões da Alma onde sustenta que qualquer alteração das paixões com vista à restituição de sua função ou utilidade tem de ser mediada em representações e associações ${ }^{61}$.

Parte da boa administração das paixões requer averiguar as forças e fraquezas da alma, o mesmo é dizer a capacidade da vontade em autodeterminar-se nos pensamentos e na conduta guiados pelo juízo. As paixões em que as percepções do sentido externo são predominantes, isto é, aquelas em que o corpo é proeminente, são acompanhadas de ideias turvas, sendo esse claramente o caso do amor ${ }^{62}$. Descartes enaltece o papel da palavra como instrumento de correcção exclusivo do Homem que permite restituir a regularidade das paixões ${ }^{63}$, dispondo a alma "à vouloir les choses que la nature dicte nous être utiles \& à persister en cette volonté" ${ }^{64}$.

Na sua correspondência com o embaixador Hector-Pierre Chanut, o filósofo mostra-se ciente da importância que as quatro paixões infantis terão no desenvolvimento individual, dividindo-as em duas escalas, da alegria à tristeza e do amor ao ódio, afecções na origem dos primeiros sentimentos e disposições. Essas são paixões inatas originadas no momento da concepção, com a unidade entre corpo e alma, mas Descartes sublinha o modo como são moldadas pelo processo formativo ${ }^{65}$. Salientando tal como nas Paixões da Alma a especificidade dos movi-

${ }^{60}$ Cf. Les Passions de L'Âme, I, AT XI, art. 46.

${ }^{61} \mathrm{Cf}$. Les Passions de L'Âme, I, AT XI, art. 45.

${ }^{62} \mathrm{Cf}$. Les Passions de L'Âme, I, AT XI, art. 27.

${ }^{63}$ Cf. Les Passions de L'Âme, I, AT XI, art. 50.

${ }^{64}$ Les Passions de L'Âme, II, AT XI, art. 52, p. 372.

${ }^{65}$ A mesma ênfase na conjugação entre a constituição fisiológica do indivíduo e o seu percurso biográfico pode encontrar-se em Les Passions de L'Âme, I, AT XI, art. 48 , pp. 366-367. 
mentos corpóreos associados a cada um dos afectos, tendo o coração como centro de activação dos movimentos dos espíritos animais, Descartes salienta a proximidade entre o amor e o ódio. Sustenta que ambas as emoções têm latente o desregulamento ou confusão (déreglements) do sentido interno, sendo que em função da concretização ou frustração do desejo [désir], é possível a mescla ou inversão dos afectos. Contudo, de forma mais diferenciada, o amor envolve uma aceleração da circulação e o envio dos melhores e mais leves espíritos ao cérebro, ao passo que o ódio, tonalidade próxima da cólera, predispõe a distúrbios digestivos em função do maior torpor da circulação e está associado à "amargura do sal \& a acerbidade do baço"66.

No seu conceito mais simples o amor respeita à vontade do sujeito possuir ou juntar-se aos objectos que parecem convenientes ${ }^{67}$. Contudo nas formas mais complexas ele requer uma projecção da evolução temporal e a consideração dos anseios do outro ${ }^{68}$, é à conjugação dessa avaliação que Descartes chama desejo ${ }^{69}$. O que distingue o amor, em particular o amor dito concupiscente ou sensual é o papel da imaginação sobre a memória. A imaginação permite, enquanto faculdade da alma, não só descobrir e projectar qualidades no objecto de desejo doutro modo invisíveis ou indiferentes, mas é por seu intermédio que o sujeito vem a urdir a ideia de uma unidade de si-mesmo com alter ${ }^{70}$. Essa unidade deve contudo ser distinta da posse do objecto que Descartes aproximaria do desejo erótico, mas requer uma autonomia e reciprocidade do amado. No artigo 97, já depois de especificar as diferentes paixões que participam no amor de modo distinto e o modo como nelas o sentido da visão é predominante, nota como essa afecção da alma é acompanhada pela aceleração do pulso, pelo calor no peito e a promoção do processo digestivo. É assim de parecer que tal como na paixão alegria, se permanecer regular, o amor sensível mobiliza os espíritos mais finos e leves do coração ao cérebro promovendo pensamentos benéficos e saudáveis.

\footnotetext{
${ }^{66}$ Carta a Chanut de 1 de Fevereiro de 1647, AT IV, p. 615.

${ }^{67}$ Cf. Les Passions de L'Âme, II, AT XI, art. 79.

${ }^{68}$ Cf. Les Passions de L'Âme, II, AT XI, art. 82.

${ }^{69}$ Cf. Les Passions de L'Âme, II, AT XI, art. 86.

${ }^{70}$ Cf. Les Passions de L'Âme, II, AT XI, art. 90, p. 396 e AT IV, p. 607.
} 
É certo que nessa leitura que integra o organismo e seus processos fisiológicos nas relações sociais Descartes continua a reger-se por valores tradicionais. Porém, nas suas preleções éticas o que encontramos é a referência à dimensão regulativa do uso das paixões, um inquérito provisório que mesmo remetendo para a sabedoria da natureza, não propõe uma resposta unívoca para a utilidade das paixões.

Na literatura moralista, nomeadamente de máximas, encontramos uma viragem semântica relativa ao uso dos prazeres e à sua avaliação moral $^{71}$. La Rochefoucault e Pascal atentam à inserção das variantes do amor-próprio nas relações sociais. Isso é particularmente notório no caso do amor apaixonado, e também neste a construção da auto-estima assenta na mediação comunicativa. Falamos aqui de um sentimento socialmente construído que não pode resumir a complexidade das emoções amorosas, mas fornece o mecanismo de base da projecção de uma imagem de si-mesmo no outro, aguardando a sua aprovação ou subscrição. Como vemos nas Lettres, se bem que tenha origem na conjunção entre a memória e o labor imaginativo, o sentimento é reforçado pelas sensações agradáveis e intensas da corporeidade advindas da interacção com o outro, formas de retroalimentação do sentimento inicial. Subjacente à projecção como base identificativa do sujeito está sempre o controlo da sua própria imagem e da imagem do outro. Contudo é precisamente o corte abrupto ou a interrupção desse circuito que é dramatizada pelo autor implícito das cartas.

Essa viragem significa em grande medida o abandono mais ou menos explícito da ideia das paixões naturais, pois os novos temas, sobretudo a articulação narrativa do desejo passa a estar dependente do próprio tempo social. A acção e co-acção dos amantes não dita apenas a consumação do apetite, mas também as suas modulações como desejo dependente de interacção temporal e socialmente regulada.

$\mathrm{Ph}$. Stewart expôs o modo como os romances do século XVII integram uma nova terminologia que valoriza a dimensão passional, descobrindo mais que o seu sofrimento ameaçador da identidade. São diversos os percursores de uma mutação na concepção dos sentimentos que

${ }^{71}$ Cf. Catherine Newmark “...le plus de douceur en cette vie...” Moralistik, Sensualismus und der Geschmack von Passionen im 17. und frühen 18. Jahrhundert" in Sabrina Ebbersmeyer, Emotional Minds. The passions and the limits of pure inquiry in early modern philosophy, Berlin/Boston, De Gruyter, pp. 179-190. 
por vezes confinamentos de antemão ao século das luzes ${ }^{72}$. As Lettres como será reconhecido por Stendhal não devem ser tomadas somente como antecipação do código do amor-paixão mas seu representante maior.

\section{Observações da Paixão}

Findo este excurso onde abordamos as práticas literárias, as teorias médicas do processo curativo e a evolução na consideração das paixões da alma, procuraremos de seguida destacar com maior precisão alguns dos pontos das Cartas Portuguesas onde tais aspectos se dão a ler.

Com vista à preservação da complexidade do género epistolar manteremos como operatória a divisão entre dois níveis paralelos, um primeiro baseado no tempo da escrita "vivida" do autor implícito, sujeito da enunciação, um outro concernente ao labor do autor suposto das Lettres. Esta "partição" permitirá aceder a algumas das crenças e pressupostos do autor, mas também às reacções que o mesmo pretendeu activar junto do público. É a partir dessa mesma "partição" que se constrói a referência múltipla que permite uma designação coerente de Mariana enquanto sujeito de desejo.

A “composição" da paixão envolve uma relação com o corpo (orgânico-somática) e suas fontes de prazer, com a consciência afectada que narra a própria vivência e com os recursos linguísticos que lhe permitem tornar inteligível as afecções.

O primeiro momento remete para o "tratamento" auto-referencial da paixão por parte do autor implícito das missivas (Soror Mariana Alcoforado). Aquilo que irá acicatar a sucessão das cartas é precisamente a ausência de uma repercussão ao nível da comunicação e projecções que caracterizam a paixão amorosa. É a partir daí que se assiste a um trabalho de reorganização psíquica dos conteúdos da consciência, no qual se concentra de um modo sintético a transformação valorativa do objecto retido na memória.

72 Cf. Philip Stewart, L'Invention Du Sentiment: Roman et Economie Affective Au XVIIIe Siècle, Oxford, Voltaire Foundation, 2010. 
O segundo respeita ao papel do suposto autor das cartas (Gabriel Guilleragues), não só como aquele que "forja" a autenticidade das mesmas, mas também como observador de segundo grau da paixão e do modo como esta está em estrita dependência do código comunicativo do amor. É o apagamento da barreira entre o fáctico e o ficcional que permite a criação de um cenário de crise da crescente comunicação epistolar ${ }^{73}$, ao mesmo tempo que mantém a sua linearidade e a intensidade, características que a aproximam da escrita autobiográfica e do seu "presumível" acesso ao fluxo da consciência ${ }^{74}$.

Nas missivas de Mariana não há um pacto autobiográfico que uniria autor, narrador e personagem ${ }^{75}$, mas um comprometimento efectivo na relação sempre triangular entre signatário/amante, carta e destinatário/amado. Contudo, se tivermos em consideração a composição do suposto autor Lettres esse último vértice será ocupado pelo leitor. Além da fruição, a leitura das cartas pode ter um uso pedagógico ou evolver para formas de identificação do leitor com as diferentes estações do pathos de amor.

É somente integrada num sistema comunicativo diferenciado que a paixão deixa de ser -adaptando os termos de Luhmann- simplesmente uma "anomalia" passando a "normalidade totalmente improvável", geradora de vínculos de parentesco e de uma fronteira constitutiva da intimidade ${ }^{76}$. Já nos finais da idade média os sintomas de amor, o deses-

${ }^{73} \mathrm{Em}$ A Arte da Sociedade, N. Luhmann tomou esta revisão da relação entre o fáctico e o fictício como essencial às novas formas literárias que devem reposicionar o espectador relativamente ao curso diegético, seja reescrevendo a ficção dentro da ficção (o modelo quixotesco), seja apresentando a indistinção entre o real e o ficcionado (o modelo das “cartas encontradas"), cf. Id., Die Kunst der Gesellschaft, Frankfurt a.M., Surkamp, 1995,p. 414.

${ }^{74}$ A autobiografia e a escrita epistolar partilham "the impossibility of giving a convincing portrait of the hero physically or mentally, without self-consciousness" Mas " $[\mathrm{t}]$ he autobiographical narrative, has, moreover, a peculiar disadvantage in that the flow of events in the life of the narrator is arrested while he recounts the past, and the vividness one would expect from a personal relation is often lessened by the deflection of interest from the living narrator to the happenings he describes" Bridget G. MacCarthy, The Female Pen: 1621-1818, New York, New York University Press, 1994, p. 242.

${ }^{75}$ Cf. Philippe Lejeune, Le pacte autobiographique, Paris, Seuil, 1975.

${ }^{76}$ Niklas Luhmann, Liebe als Passion. Zur Codierung von Intimität, Frankfurt a.M., Suhrkamp Verlag, 1982, p. 10. 
pero e a submissão à mulher, alvo de uma espiritualização sem precedentes, começam a ser mais que padecimentos da Liebeskrankheit. Pela necessidade de os dominar e verter na escrita esses sinais são também usados para atestar a pertença ao mundo cortês e a um género ${ }^{77}$.

A observação de segunda ordem é exclusiva do autor, daquele que apresenta o jogo amoroso mantendo para si a completa configuração da relação, o conjunto de pressupostos de cada um dos participantes nos pólos da acção e vivência, que serão desvelados na escrita de "Marianne" $"$. O conhecimento integral das expectativas e projecções do outro por parte daqueles que participam no jogo quebraria um dos seus requisitos, justamente aquele que concerne à autonomia recíproca dos participantes. A interacção comunicativa que encerra Mariana na observação do amante e da sua própria paixão tem subjacente a inacessibilidade da vivência psíquica de outrem e como tal, um controlo sempre ilusório dos seus temas.

\subsection{A paixão de Mariana}

O "progresso" da vivência emocional de Mariana revela a mobilidade da paixão em face da resposta insuficiente relativamente ao seu investimento, i.e., a impossibilidade de, em virtude da quebra comunicativa, aceder a um "recipiente" adequado para os seus anseios. É neste primeiro eixo, concernente à observação de primeira ordem, que a crise na concepção antropológica clássica das paixões é notória. Tal esquema seria incapaz de tematizar a paixão amorosa de cariz sensório, não tanto por força da divisão estanque das partes da alma (imaginativa, racional e mnemónica) e dos temperamentos, mas sobretudo por não conceber a mobilidade e designação complexa das emoções subjectivas.

É no novo paradigma antropológico que emerge nos finais da idade média encontramos afinidades entre a condição melancólica e os estados de Mariana após a interrupção do seu desejo. Nas concepções da

${ }^{77}$ Cf. e.g. Ionn Couliano, Eros and Magic in the Renaissance, Chicago, University of Chicago, 1987, pp. 18-23.

${ }^{78}$ Figura ficcional que distingo da figura histórica de Mariana Alcoforado que, nas palavras de BALSEMÃo PIRES, é: "demasiado verosímil para poder ter sido pura ficção de um libertino francês” cf. Id., "J'ai éprouvé...”, pp. 68-72. 
melancolia erótica a etiologia vai além da estrita dimensão fisiológica e daquela em que as paixões são expressão de uma ordem cósmica que determinaria o tipo de humores e sua distribuição. Mas só em meados do século XVII começa a generalizar-se a viragem operada por autores como Montaigne e a paixão deixa de ser tomada como acidente relativamente a faculdades estáveis essenciais ao humano e passa a ser considerada como fonte digna de inspecção e conhecimento ${ }^{79}$.

Ainda que nas Lettres se indique a ausência de correspondência por parte do amado, que se furta a uma interacção efectiva, além do muro silêncio há por certo um ressoar mínimo das acções do cavaleiro, informações que Mariana obtém relativamente ao mundo exterior. Aparte das ténues reacções e silêncio do amado, tais mensagens são obtidas em especial por via da relação que mantém com os membros do claustro que lhe veiculam os rumores e conjuntura histórica, costumes de socialidade da corte francesa... Isso permite sustentar que a sua clausura é apenas parcial, permitindo modos vários de hetero-referência.

Um dos aspectos que se agudiza nas construções literárias relativas ao enlace amoroso é o tema da incompreensão das volições ou movimentos por parte do sujeito da enunciação ${ }^{80}$. A cultura epistolar responde à necessidade de que a paixão encontre "uma linguagem própria e signos autênticos para revelar um pensamento concebido como indissociável da percepção singular das coisas" $"$.

Este é um tema crucial que marca a progressão nas Cartas da irmã de Beja e que surge primeiramente na sua retrospecção sobre as fontes do prazer físico. Mas o prazer na sua vertente física fica como um dos primeiros ou mais baixos modos de vínculo entre os amantes. Como dirá Stendhal, nos seus "transportes" as formas de amor-paixão, de que as Lettres Portugaises são o mais puro exemplar, "font presque

${ }^{79}$ Mas, como notou Michael Moriarty: "the psychological is not apprehended separately from the ethical: passions and desires are seen as colouring and shaping the whole of our lives, and as requiring to be judged in that perspective: they are not studied as discrete mental processes" Id., Fallen Nature, Fallen Selves Early Modern French Thought II, New York, Oxford University Press, 2006, p. 23.

80 “[L]a passion est-elle toujours liée à une âme en mouvement et c'est ce mouvement même qu'il faudra s'employer à lire et à déchiffrer” LuCIE DESJARDINS, Le corps parlant: savoirs et représentation des passions au XVIIe siècle, Laval, PU Laval, 2001, 59-60.

${ }^{81}$ L. DeSJARDins, Le corps parlant..., p. 262. 
fait oublier les plaisirs du corps" $"$. Nas Lettres é sugestivo que esse prazer ou conturbação dos corpos seja identificado com o movimento inicial, posteriormente retido enquanto traço mnésico ao qual o sujeito retorna transcendendo, através de sucessivas modelações imaginativas, a circunstância empírica do objecto que o suscitou. Mariana descobre na relação com alter o modo como a conturbação dos sentidos pelo movimento da paixão -iniciado no momento em que avista o cavaleiro da "janela de Mértola"- se transmuta em tonalidades emocionais mais ricas. As emoções não cessam com a saída de cena do outro, elas retornam desfigurando-o e aproximando-o de um objecto ideal cuja indiferença torna insuportável a vida da religiosa. Inspirado no fenómeno de metamorfose observado nas minas de Salzburgo, Stendhal denominou o modo de retroalimentação do amor de "cristalização" 83 conducente à fixação psíquica do objecto de amor. Essa cristalização procede do desejo ou impulso inicial transfigurado numa sucessão de camadas resultante de mecanismos de admiração, prazer, esperança e dúvida. $\mathrm{O}$ ápice da cristalização da paixão, que eleva o outro a objecto de amor, ocorre quando depois dessa sucessão de camadas o amante está convicto da singularidade absoluta da[o] amada[o] e "des plaisirs qu'elle seule au monde peut me donner" 84 . É a partir daí que tem lugar uma errância movida pelo objectivo da prova, da confirmação de que é possível uma reciprocidade do sentimento do outro.

$\mathrm{Na}$ observação dos seus próprios objectos interiores, pela transposição para a escrita e apropriação reflexiva, revela Mariana uma capacidade para reorientar as causas da paixão e assim alterar as suas elaborações narrativas ${ }^{85}$. Se em Mariana encontramos uma alusão às emoções como elementos pré-comunicativos é já como metáfora dos "movimentos" interiores da alma submetidos às exigências de inteligibilidade e sintaxe, com recurso a designadores e a actualização sucessiva do pronome "eu". Um aspecto assinalável é que Soror Mariana

${ }^{82}$ Stendhal, De l'Amour, Paris, Garnier Frères, 1906 [1822], p. 3.

83 “Ce que j'appelle cristallisation, c'est l'opération de l'esprit, qui tire de tout ce qui se présente la découverte que l'objet aimé a de nouvelles perfections" StendHAL, De l'Amour, p. 5. Cf. Ibid., pp. 324-335.

${ }^{84}$ Stendhal, De l'Amour, p. 8.

${ }^{85}$ É o que na teoria dos sistemas se descreve como série sucessiva de reentradas da observação na observação. 
revela uma considerável dinâmica na organização interna das afecções. A tematização emocional, capaz de processos de interiorização e posterior reconfiguração imaginativa do objecto, decorre de uma superação "metafórica" dos movimentos de que se diz "vítima". Todavia, sem a referência a um simbolismo, estes elementos proto-comunicativos ficariam cativos de uma inefabilidade, que no endereçamento da religiosa se mantém mas somente enquanto recurso retórico pelo qual apela à comiseração do amado.

Estes aspectos teóricos (relativos aos "transportes" da paixão) assumem relevância em vários pontos das Cartas devendo ser conceptualizados não primeiramente como uma sucessão de fases, mas como evolução de um "campo de tensões psíquicas". Noto de antemão (antecipando o ponto seguinte) que estes aspectos não se reduzem à vivência individual, mas têm como condição de possibilidade a participação de um leitor que mobiliza aspectos da sua vida inconsciente e também as representações sociais relativas sobretudo às posições de género, bem como à descoberta e manifestação adequada do amor. É na presença destes aspectos solicitadores de empatia e interpretação que reside a riqueza deste texto que, ao mesmo tempo que suscita as reapropriações de que veio sendo objecto até aos nossos dias, a elas se furta constantemente.

Irei de seguida destacar alguns dos momentos desse "progresso" temporal, num excurso que não se pretende totalizante.

No momento inicial das Cartas assiste-se a um aprofundar da auto-observação subsequente à identificação projectiva ${ }^{86}$ coincidente com a "elevação" do amado a objecto interno do ego. Esta projecção corresponde a uma divisão do ego decorrente do abandono de uma posição narcísica. Esse primeiro momento envolve uma erotização do objecto por via de retrospecções do envolvimento amoroso. A religiosa expressa não apenas a excepcionalidade do vínculo como vai imputar no outro o sentimento de uma complementaridade e sintonia absolutas: "je vous assure que vous ferez bien aussi de n'aimer personne. Pourriez-vous être content d'une passion moins ardente que la mienne?"87. Está aqui

${ }^{86}$ Uma apresentação das especificidades deste mecanismo descrito pela Psicanálise foi desenvolvida por BALSEMÃo PIRES na leitura das Lettres, cf. Id. “J'ai éprouvé...", pp. 33-80.

${ }^{87}$ Mariana Alcoforado, Lettres portugaises Traduites en François, Paris, Claude Barbin (ed.), 1669 (Doravante usarei a sigla SMA), pp. 14-15, 1ère lettre. 
repercutida a influência da concepção de amor platónico recuperada no Renascimento. A inércia da paixão, a sua tendência conservadora é explicada pela projecção em alter de uma singularidade sem qualquer paralelo no mundo. Esta idealização da relação mútua procedente da projecção envolve já uma primeira e determinante tensão que a ausência de um retorno comunicativo irá acentuar. $\mathrm{O}$ objecto perdido começa a ser alvo de reconfigurações que revelam a ânsia de uma manutenção do investimento imaginário ${ }^{88}$.

Após experienciar a exaltação do reencontro com o objecto perdido e ser capaz de o reformular imaginativamente, o sujeito julga poder activar por si só as fontes de realização emocional que o mesmo fornecia. Na terceira carta, a irmã de Beja manifesta, ainda de modo parcial (i.e. sem prescindir do cavaleiro francês) a secundariedade do objecto amado em face da retribuição do movimento interior da paixão: "vous auriez éprouvé qu'on est beaucoup plus heureux, et qu'on sent quelque chose de bien plus touchant, quand on aime violemment, que lorsqu'on est aimé" ${ }^{89}$. Contudo, este é ainda um recurso pelo qual que convoca à incondicionalidade da entrega do outro. É o apelo a uma constância capaz de conter a angústia causada pela sua saída de cena, momento em que a tristeza que caracteriza a melancolia amorosa acomete a vida psíquica de Mariana. O desinvestimento do objecto é equivalente a uma perda de valor do próprio ego, algo que este tenta desesperadamente prevenir $^{90}$.

$\mathrm{Na}$ terceira carta as projecções de dúvida e indicações de angústia acompanham o oscilar entre o sacrifício incondicional e a circunstancialização da sua entrega. Mariana contabiliza aquilo que sacrificou em virtude da eleição do amado: “j' ai perdu ma réputation, je me suis exposée à la fureur de mes parents, à la sévérité des lois de ce pays contre les religieuses, et à votre ingratitude, qui me paraît le plus grand de tous les malheurs..."91.

88 " $[\mathrm{N}] \mathrm{e}$ devais-je pas prévoir que mes plaisirs finiraient plus tôt que mon amour?" SMA, pp. 29-30, 2ème.

${ }^{89}$ SMA, pp. 58-59.

90 "N'ayant enfin à combattre que contre moi-même, je ne pouvais jamais me défier de toutes mes faiblesses, ni appréhender tout ce que je souffre aujourd'hui" (SMA, pp. 53-54, 3ème).

${ }^{91}$ SMA, p. 63. 
Tal como era referido nos escritos sobre o amor hereos, surge aqui a ideação suicida, ensaio de uma prova de amor inequívoca capaz de lacrar de modo irreversível o sentido da sua própria existência: "une fin tragique vous obligerait sans doute à penser souvent à moi, ma mémoire vous serait chère, et vous seriez, peut-être, sensiblement touché d'une mort extraordinaire; ne vaut-elle pas mieux que l'état où vous m'avez réduite?" 92 .

Além da divisão e alienação mental, observa-se o surgimento de mecanismos persecutórios, culminando no retorno ao estado depressivo. Esses mecanismos são desencadeados não somente pelo amado -"ce procédé est bien plus d'un tyran, attaché à persécuter, que d'un amant, qui ne doit penser qu'à plaire" ${ }^{93}$-, mas também pela própria família - "Votre famille vous avait écrit, ne savez-vous pas toutes les persécutions que j'ai souffertes de la mienne?"94.

Mas, mesmo nos momentos em que considera o arrependimento, nunca admite Mariana a hipótese de o vir verdadeiramente a sentir. Em conformidade com a fisiologia cartesiana a sua linguagem remete para o coração como órgão em torno do qual têm lugar as manifestações e a persistência do amor, agradecendo ao amante o acesso a tal experiência: "je vous remercie dans le fond de mon coeur du désespoir que vous me causez, et je déteste la tranquillité où j'ai vécu avant que je vous connusse" ${ }^{95}$. Os movimentos do corpo e da alma que acompanham o amor assinalam um passo irreversível, instauram um jubiloso conhecimento de si próprio que mesmo que mitigado deixa uma marca indelével: “[n]'éprouvé-je pas qu'un cœur attendri n'oublie jamais ce qui l'a fait apercevoir des transports qu'il ne connaissait pas" ${ }^{\prime \prime}$.

Por várias ocasiões ao longo das cartas encontramos também os sinais da aegritudo amoris: as lágrimas e o choro compulsivo após o afastamento, o abatimento generalizado similar à acedia monástica, o ensimesmamento e indiferença relativamente ao mundo quotidiano e o instinto suicidário. Mas um dos sintomas apontados por Burton, que deriva ainda da tradição que aproxima os certos traços da melancolia

\footnotetext{
92 SMA, pp. 69-70, 3ème.

93 SMA, pp. 89-90 4ème.

${ }^{94}$ SMA, pp. 92-93 4ème.

95 SMA, pp. 74-75 3ème.

96 SMA, pp. 147-8 5ème.
} 
e com a genialidade, é aquele da propensão do amante para a loquacidade, em particular para a poética.

A ideia de um sofrimento que tolda todas as observações do mundo e põe o indivíduo em contacto com a causa e sentido da sua própria existência é o elemento fulcral da nova concepção de intimidade, espaço comunicativo gerado na eleição amorosa. Esta inovação na semântica do amor tende, em condições normais, a inserir-se numa dialéctica -aqui interrompida- entre a consumação intensa dos amantes e a realização de um projecto partilhado, a reprodução da paixão no tempo. Por outro lado, as novas condições de diferenciação social exigem que as paixões violentas sejam contidas na relação dual, pois nesta os vínculos sociais da simpatia como cimento das relações morais absorvem elementos pulsionais sem mediação adequada. O contacto amoroso que fora considerado pecaminoso passa a estar regulado no domínio privado, e certas paixões que a moral tradicional sancionava, como é caso da inveja (na forma de ciúme), passam a ser valorizadas como parte do código do amor-paixão.

A cessação das cartas pode indicar a saída do conflito cognitivo, a resolução de um paradoxo que é o da prisão amada. Na sua observação retrospectiva das sequências passadas o paciente parece incapaz de compreender o motivo pelo qual recorreu ao "endereçamento" comunicativo compulsivo uma vez que este objecto lhe parece agora odioso ou simplesmente prescindível. A revelação da verdade da fantasia, do objecto que se idealizou como fim da paixão, o seu atravessamento, aqui significando o recolhimento e libertação da fixação passional, é assim equivalente a uma nova capacidade de observação que age retrospectivamente sobre os eventos passados, na significação dos mesmos e na sua vivência interior.

O exercício da imaginação que encontramos em Mariana, numa narração que reteve e trabalha o objecto da paixão, pode na verdade ser entendida como alternativa às difundidas crenças em filtros (poções, amuletos e magias diversas) que procuram superar obstáculos ou encantar o amado, bastante difundidos na medicina humanista ${ }^{97}$. Esse predomínio do encantamento por via do magismo tem repercussões na

${ }^{97}$ Cf. e.g., Ferrand, De la maladie d'amour..., pp. 222-229 e Burton, The Anatomy of Melancholy..., 3.2.2.5 
literatura onde é frequentemente exposta a prática do philocaptio, feitiço que permitia ganhar a paixão do outro sem que ele se apercebesse ${ }^{98}$.

A correcção das paixões amorosas danosas por via da arte e retórica poética havia sido considerada por Ovídio no Remedia amoris, onde além de causa, a poesia se propõe como antídoto da patologia contraída. Será possível encontrar nas Lettres um modelo similar em que a função da poesia, neste caso da novela, está, se assim o podemos dizer, contra si própria? As Lettres subscrevem a ideia de um período de incubação, a partir de um certo momento o contágio, decorrente da exposição à violência das emoções, é irreversível ${ }^{99}$. É certo que algumas das principais indicações terapêuticas propostas por Ovídio estão interditas a Mariana. É esse o caso das distrações (pela diversão e viagens) e do trabalho, remédios similares aos constantes nos tratados sobre a melancolia erótica. Outra advertência essencial para reverter a paixão amorosa é evitar a solidão, mas segui-la colidiria com a condição mesma da redacção de cartas. Nas palavras do poeta, é a solidão e o fechamento ao exterior que tende a presentificar a imagem do objecto perdido ${ }^{100}$. As alternativas terapêuticas passam pela eleição de outro objecto de desejo e pela via que Mariana segue até certo ponto, a detracção e questionamento das qualidades do amante (a par com o putativo corte de relações). Segue-o apenas parcialmente porque não deixa de reconhecer que foi por intermédio do amante que lhe foi revelada uma faceta de si-mesma doutro modo inacessível. O exame da paixão permite, através do distanciamento e observação reflectida, corrigir, ou pelo menos amenizar, os devaneios. As cartas representam o trabalho da faculdade rememorativa e imaginativa, é por via da recolecção do passado à luz do sofrimento presente que a fixação inicial é trabalhada. É assim que na quita carta o corte irreversível é apresentado num outro recurso clássico da cura de amor, Mariana assegura-se que ofertas do cavaleiro serão devolvidas ${ }^{101}$.

${ }^{98}$ Essa prática está baseada no exercício da imaginação sobre as características do outro sexo, que tende cada vez mais a integrar também características específicas do indivíduo, cf. Folger, „Geschlechterentwürfe...”, pp. 139 e ss.

99 "principiis obsta: sero medicina paratur/ cum mala per Iongas convaluere moras" Publius Ovidius Naso, Remedia amoris - Heilmittel gegen die Liebe, Stuttgart, Philipp Reclam jun., 2011, p. 12 (91-92).

${ }^{100}$ Cf. Ovidius, Remedia amoris, p. 50 (581-585).

${ }^{101}$ SMA, pp. 49-50. 
Após a descrição tão concordante com o processo de arrefecimento do sangue e abrandamento da pulsação, a via indicada nas cartas não passa pela restituição de um amor sui, dependente de um outro empírico, mas pelo amor Dei. A linguagem do endereçamento místico parece sempre latente nas cartas, mas a posse plena da paixão só é possível após este desvio que contrapõe as flutuações do coração à entrega inequívoca ao Senhor ${ }^{102}$.

\subsection{A paixão por "Marianne"}

Certos tipos de relação dual, como é o caso da epistolar e a terapêutica, tendem a revelar uma intencionalidade além do fechamento numa teoria da representação. Neles surge uma constante re-selecção daquilo que vem a assumir relevância psíquica e comunicativa, em especial na exploração da dimensão "inconsciente".

Um tema relevante mas impossível de tratar aqui em toda a sua extensão é o do modo como as Lettres se posicionam em relação ao predomínio da elegância retórica. Também em virtude do uso de um estilo que parece romper a barreira da escrita e aproximar-se de uma oralidade espontânea, as Lettres parecem alheias à composição escrita que almeja produzir sentimentos de prazer na contemplação do belo. Naquele que é o seu pendor claramente polemista, selectivo dos pontos de irritação da sociedade do século XVII, o texto aborda temas sob fortes disputas semânticas em diferentes instituições e entre os representantes da cultura letrada da época. Assim, em cinco cartas onde se desenrola uma paixão "natural", se concentram a problematização da posição da mulher religiosa, do papel de cada um dos sexos no jogo da sedução, da honorabilidade masculina, e concernente ao tema de que nos ocupamos, da auto-observação e legitimação da paixão amorosa. Deste modo, ao conceber as paixões como forma de auto-afecção não está em causa unicamente a geração de uma identificação empática dos leitores com as tribulações de Mariana, mas também uma reflexão sobre a significação social das emoções e sentimentos mais intensos e certamente a sua consideração além dos binómios útil-nefasto; saudável-patológico.

${ }^{102}$ SCHRÖDER, “Les méditations de Marianne...”, p. 284. 
As Lettres apresentam um processo de descoberta mútua presente num vínculo peculiar entre remetente e destinatário -neste caso o leitor- o qual de certo modo reproduz a relação entre amante e amado ${ }^{103}$. Dois acoplamentos do sistema psíquico são aqui cruciais: aquele com os conteúdos interiores que se revelam na modalidade emocional e um outro com a posição simbólica e fixação comunicativa de expectativas relativas à paixão. Este segundo aspecto confere às Lettres um lugar de destaque na história da literatura pois nelas se cumpre um desígnio que a sociedade vai impor à ficção literária e que entronca na comunicação epistolar como génese mesma do romance. Esse desígnio consiste na criação de formas simbólicas estáveis e reprodutíveis, que não só orientam o sistema psíquico na interpretação dos movimentos emocionais, como lhe fornecem uma instância de observação valorativa. Analisando diversos textos do século XVII onde o género foi tematizado a partir de conflitos latentes, U. Kundert mostrou que essas instâncias de observação fornecem o contexto de acção e significação possível constituindo o epicentro conflitual da normatividade ${ }^{104}$.

Nas Lettres, além de se promover a exploração e narração conjunta dos objectos interiores, sobressai a imposição de expectativas normativas, indicativa de uma apropriação e transformação de aspectos conflituais presentes na semântica da paixão. Deve assim indagar-se o modo como a espontaneidade verosímil da narração, interpretação e empatia com os estados interiores do outro é ela mesma o resultado de uma transposição de expectativas de género, mas sobretudo da adopção selectiva do código amoroso, onde a ideia de "regularidade moral" é, por assim dizer, suspensa ${ }^{105}$.

${ }^{103}$ R. BARTHES defendeu que é desde logo o leitor do romance que está cativado na ausência de resposta, pois debate-se com um personagem que fala consigo mesmo "enamoradamente", que lhe fornece os guias do sentimento e do comportamento apaixonado, mas por fim o abandona à sua sorte, cf. Id., Fragments..., pp. 6-10.

104 „Die Beobachtungsinstanzen bieten sich den Lesenden als Hilfe an, damit sie sich an ihnen die normativen Erwartungen ihrer Umgebung vorstellen und ihre Handlungen nach ihnen ausrichten, also normenkonform handeln können" URSULA KUNDERT, Konfliktverläufe Normen der Geschlechterbeziehungen in Texten des 17. Jahrhunderts, Berlin, Walter de Gruyter, 2004, p. 242.

${ }^{105}$ De acordo com U. KunderT, as normas de género que estão presentes na variedade de textos produzidos no século XVII são categorizáveis pela sua relação 
A comunicação epistolar constitui-se como meio de afirmação pragmática do si mesmo, mas consegue-o apresentando a articulação subjectiva dos fragmentos de amor presentes no código da galanteria e da sedução, os quais eram veiculados na "literatura de máximas" e nos códigos de conduta dedicados à temática do comportamento amoroso, fornecendo instruções e exemplos ${ }^{106}$. Não é casual que Marianne se enderece ao seu amante não apenas provida de recursos retóricos próprios daquela semântica cortês, mas também rejeitando alguns dos seus princípios.

Uma das ocasiões que testemunha a subscrição de parte substancial da axiomática amorosa de La Rochefoucauld tem lugar quando Marianne racionaliza acerca do sacrifício de amor, enumerando as suas perdas, lastimando o abandono da sua inscrição social (enquanto filha, irmã de sangue e soror da comunidade de devotas).

Ao mesmo tempo, a retórica da clausura que se metaforiza na captividade de amor, não se afigura senão um artifício da impossibilidade ${ }^{107}$. É a partir desta duvidosa circunscrição da freira que se articula a posição discursiva da signatária implícita das cartas.

com o sexto mandamento bíblico -Guardar castidade nas palavras e nas obras-, $\mathrm{cf}$. Id., Konfliktverläufe Normen, pp. 51-77. É no seu eixo que oscilam as posições sobretudo referentes à mulher, entre saber-inocência e a modéstia-licenciosidade. É destas oposições e pontos de tensão que surgem as exigências normativas que servem de "Beobachtungsinstanzen".

106 "Personal letters and literature become the primary discursive fields where the eccentric subject can search for and find self-identification and self-validation" EDGAR LANDGRAF, "Romantic Love and the Enlightenment: From Gallantry and Seduction to Authenticity and Self-Validation" The German Quarterly 1 (2004), pp. 29-46, p. 37.

${ }^{107}$ Nas cartas está descrita uma intensa osmose com o exterior, ao mesmo tempo que só uma resignação de Mariana a uma posição passiva explica que não se evada do convento. BARBARA R. WOSHINSKY defendeu recentemente que a efabulação do interior do convento também pressupõe a sua abertura ao exterior, cf. Id., Imagining Women's Conventual Spaces in France, 1600-1800. The Cloister Disclosed, London, Ashgate, 2010, 251. O Concílio de Trento impusera regras estritas relativas ao fechamento das congregações religiosas. O claustrum continua permeável a elementos exteriores, mas esse acesso torna-se mais restritivo, sendo justamente a segregação e inacessibilidade das mulheres puras que motiva a eleição da vida conventual como tema. É enquanto esposas de Cristo que as freiras são alvo de uma sobrecarga erótica, cf. cap. 6 da obra de Woshinsky: "Male Appropriations of the Nun's Persona". 
Guilleragues, o suposto autor das cartas, poderá estar imbuído da associação frequente à época entre a escrita feminina e a sentimentalidade desordenada. Mas tal aspecto temático parece surgir apenas no tropos de uma passividade inicial, cedência à sedução amorosa iniciada por via dos sentidos, em particular da visão, pela qual se inculca uma paixão que só se percebe como reclusão após a partida do oficial francês. Essa dimensão da passividade tem no texto relevância por remeter para um passado em que a mulher foi sujeita a um cerco amoroso, cerco que neste caso parece incendiar o claustro com a amada ainda dentro (a complacência e servidão das irmãs é a este respeito indicativa de uma turbulência generalizada). Os traços típicos de género (começado com o tema da prudência e seu equivalente feminino, o pudor) são suspensos, em face da auto-observação honesta da paixão como movimento onde está em causa a individualidade do desejo independentemente das condicionantes morais.

Também neste ponto é evidente a apresentação relativamente nova de um tema de eleição na literatura libertina que será mais tarde exposto por B. de Mandeville na sua teoria de acerca da relação entre os sexos e que figura nas obras de B. D'Argens (sobretudo em Thérèse philosophe), viz., a expressão da pulsão feminina livre de constrangimentos moralistas, na qual se reclama um conhecimento de si mesmo como sede de paixões e emoções ${ }^{108}$. Os temas cardinais dessas obras do século XVIII figuram já no teatro cómico de Molière, em particular em École des Femmes (1662) que pode ser por sua vez ser lido como versão sublimada dos princípios presentes em obras libertinas da época ${ }^{109}$.

${ }^{108}$ Cf. Jonathan Israel, Enlightenment Contested. Philosophy, Modernity, and the Emancipation of Man 1670-1752, New York, Oxford University Press, 2006, pp. 602-604. Recentemente N. Meeker propôs que a génese materialista das teorias libertinas está profundamente inspirada pelo De Rerum Natura. De acordo com a autora, a partir do final do século XVII assiste-se ao "materialismo literário" que conjuga a somatização do homem (por via das doutrinas mecanicistas) e a exploração imaginativa das fontes de prazer livres de qualquer constrangimento moral. Será aí que se insere o projecto de Sade e a sua recusa do sentimentalismo romântico-burguês como desvio relativamente à busca autêntica da realização corpórea, cf. NATANiA MEeKer, Voluptuous philosophy: literary materialism in the French Enlightenment, New York, Fordham University Press, 2006, pp.189-205.

${ }^{109}$ Deve ser mencionado o L'École des filles ou la Philosophie des Dames duplamente atribuído a Michel Millot e Jean L'Ange e publicado em 1655 uma vez que este constitui um marco na história da instrução sexual e apela ao conhe- 
Ora nessa obra, os princípios da pedagogia "imbecilizante" do "belo sexo" são subvertidos a partir das consequências da própria inocência inculcada nas raparigas.

Na sua influente Teoria do Romance, Lukács defendeu que caberá ao romancista a tarefa hercúlea de, na ausência de modelos últimos capazes de sustentar a contingência da nova diferenciação social, propor novos guias e regras que ordenem as instituições e as relações sociais, ao mesmo tempo que é capaz de reconhecer o carácter construído e a variabilidade dos costumes. Podemos sustentar que o cerne dessa teoria fora já enunciado século e meio antes por D.A. F. de Sade. No seu ensaio "Une Idée sur les Romans", Sade delineava as tarefas que recaem sobre o romancista ${ }^{110}$. Entre os princípios que o "filósofo celerado" designou está o olhar distanciado perante as actividades e costumes a par com a capacidade de recolhimento e labor imaginativo. Desse modo afirma que "le tableau des moeurs séculaires, est aussi essentiel que l'histoire, au philosophe qui veut connaître l'homme" 111 . Mas, contrastando com o procedimento do pintor, o buril do romancista é interior. De modo que : " s'il veut connaître les hommes, qu'il parle peu quand il est avec eux ; on n'apprend rien quand on parle, on ne s'instruit qu'en écoutant ; et voilà pourquoi les bavards ne sont communément que des sots " $" 112$.

Sade sublinhava ainda que o facto de o romance requerer uma atenta observação dos mecanismos da paixão e da moral não significa que o romancista tenha de se envolver emocionalmente ou moralizar a sequência de eventos que apresenta. Somente o personagem deve moralizar, não o autor. Daí a sua exortação: “[e]vite l'afféterie de la morale; ce n'est pas dans un roman qu'on la cherche" ${ }^{113}$. Estes princípios a que Sade terá sido fiel ao longo da sua obra, parecem conformar-se com o modo de observação em segundo grau da contingência envolvida na interacção, em particular na interacção amorosa.

cimento dos mecanismos de obtenção do prazer como parte da boa educação da juventude.

${ }^{110}$ Donatien A. F. De SAde, "Une Idée sur les Romans" in Id., Les Crimes de l'amour: nouvelles hérö̈ques et tragiques; précédé d'un avant-propos, suivi des idées sur les romans, de l'auteur des crimes de l'amour à Villeterque..., Bruxelles, Gay et Doucé, 1881,pp. 121-130.

${ }^{111}$ Sade, "Une Idée sur les Romans", p. 122.

${ }^{112}$ Sade, "Une Idée sur les Romans", p. 123.

${ }^{113}$ Sade, "Une Idée sur les Romans", p. 127. 
Se frequentemente a exposição da voz das femmes savantes, que no século XVII já se havia fixado como item colecionável, sendo tida por equivalente a uma escrita onde o predomínio do sensório sobre o intelecto origina a manifestação descoordenada das paixões, o que surpreende nas Lettres é que, pese embora a transição frenética de disposições relativamente ao amado, os movimentos emocionais são expressos com recurso a uma linguagem claramente ordenada pelos novos princípios da fisiologia das paixões e pela tematização do amor da segunda metade do Grand Siècle. Essa verbalização profusa destoa tanto de uma conturbação emocional como de uma posição depressiva, na qual se pode sustentar Marianne irá decair gradualmente.

Nesse sentido, é interessante notar como Marianne parece transpor para o seu acto performativo as densas observações presentes no Discours sur les passions de l'amour [1652], em particular as que respeitam ao luto do objecto amoroso: " [a]près avoir fait ce chemin, cette plénitude quelquefois diminue, et ne recevant point de secours du côté de la source, l'on décline misérablement, et les passions ennemies se saisissent d'un cœur qu'elles déchirent en mille morceaux "114.

Um outro tópico, igualmente presente nesse ensaio atribuído a Pascal, é da máxima relevância nas Lettres, referimo-nos ao declive entre o preenchimento imaginativo do amado e o aparente vazio do face a face: "[q]uand on est loin de ce que l'on aime, l'on prend la résolution de faire ou de dire beaucoup de choses; mais quand on est près, on est irrésolu. D'où vient cela?" ${ }^{115}$. Uma resposta dada a esta questão foi ensaiada por E. Pabst: ,,a passagem para a escrita epistolar é frequentemente a transposição de uma barreira atrás da qual é 'redigível' o que não seria 'dizível'" 116 . A co-presença passa a estar dependente de uma selecção comunicativa do conjunto de sinais e comportamentos adequados. Dessa "inscrição" que tem lugar nos textos contribuintes para a sensibilidade amorosa, passa a depender a motivação e o envolvimento dos amantes. Mais uma vez salienta-se a importância da media-

${ }^{114}$ Blaise Pascal, "Discours sur les passions de l'amour" in Oeuvres complètes de Blaise Pascal, T. II, Paris, Hachette et Cie, 1913 [1652], p. 54.

115 B. Pascal, "Discours sur les...", p. 56.

${ }^{116}$ EsTHER S. PABST „Die Erfindung der weiblichen Tugend. Kulturelle Sinngebung und Selbstreflexion im französischen Briefroman des 18. Jahrhunderts, Göttingen, Wallstein, 2007, p. 282. 
ção na escrita. A difusão do romance leva à estabilização das selecções de temas e significações com que se ocupam os correspondentes epistolares.

A tensão que Marianne encarna, entre as exigências de acomodação (fechamento) e a insuficiência dos reconfortos (que a levariam a manter-se na posição de "fiel" viúva) obtém uma tradução mais significativa e abrangente no plano da evolução da semântica. Ao situar os acontecimentos num país distante está em questão uma estratégia de deslocamento (à qual recorrerá também Mme. LaFayette mas na modalidade da "metástase" histórica) relativamente à claustrofobia da vida cortês, em especial relativamente ao amor que nesta se celebrava. $\mathrm{O}$ amor galante tem como pressuposto uma elevação sem precedentes da condição da mulher, capaz de administrar a sua própria conduta (não sendo simplesmente silenciada, nem o boneco de um ventríloquo), ainda que continue sujeita a um rígido código do decoro, critério da sua inclusão.

Face aos ataques dos moralistas, em Traité de l'origine des romans [1670], P.-D. Huet, possivelmente atento à lição de Molière, salientou o papel do romance na formação da consciência moral das jovens. Só o conhecimento dos motivos do amor, e do modo como ele ateia as paixões pode prevenir a cedência completa ao desencadear autónomo do seu jogo. É a partir desse conhecimento e não de uma castidade inscrita na natureza que a mulher resiste ao cerco do amor. A este respeito afirma o autor que: "[l]es hommes ont (...) été obliges d'assiéger ce rempart par les formes, et ont employé tant de soin et d'adresses pour le réduire, qu'ils s'en sont fait un art presque inconnu aux autres peuples"117.

É justamente a este amor refinado, que exige a aplicação estrita de códigos de comportamento para participar no seu jogo, que Marianne

${ }^{117}$ Pierre Daniel Huet, Traité de l'origine des romans. (Suivi d'observations et de jugemens sur les Romans Français; avec l'indication des meilleurs Romans qui ont paru, sur-tout pendant le diz-huitieme siecle, jusqu'à ce jour), Paris, Desessarts, 1799, p. 122. A divisão entre os géneros é um dos esquemas sociais que funciona em sucessivas criações literárias como limitava das emoções, em particular da violência ameaçadora envolvida na paixão amorosa. Não se trata simplesmente de sublimação mas, em grande medida, da reorientação da paixão para um domínio separado da vida pública. A proximidade entre os termos e a semântica da paixão com a da guerra são bem claros, refiram-se a violência presente ou eminente e o tributo ao amado ou ao Senhor (ou cidade) que se serve, sendo que as duas actividades enfrentam o desafio de encontrar regras. 
imputa uma espécie de comércio dos sentimentos que a sua devotio, enquanto dom absoluto reprova veementemente: “...vous aviez fait de sens froid un dessein de m'enflammer, vous n'avez regardé ma passion que comme une victoire, et votre cœur n'en a jamais été profondément touché" 118 . Esta denúncia de um artificialismo, que reduz a co-orientação dos amantes a formas superficiais de gratificação redundando no amor-próprio, parece necessária à evolução da semântica do amor, permitindo a sua expansão além dos cálculos utilitários, implicando ademais uma integração particular do código moral e da sua oposição honesto-desonesto. A afirmação da paixão como prioritária relativamente às exigências morais vigentes é um elemento crucial do código do amor como paixão: “je sens vivement la honte des crimes que vous m'avez fait commettre, et je n'ai plus, hélas! la passion qui m'empêchait d'en connaître l'énormité..."119.

A recusa das convenções é indicativa de uma deriva romântica. Marianne abandona a passividade feminina e afirma-se como predadora de um indivíduo que apesar de reduzido a objecto da sua pulsão nunca é totalmente despersonalizado. Estamos perante uma variante da ars amandi trovadoresca. Nas Lettres o objecto de amor não é já a mulher aristocrata mas o próprio sedutor, e, mantendo como traço distintivo a entrega amorosa, o sujeito poético interiormente dividido apresenta-se como mulher ${ }^{120}$. Ponto mais decisivo é aquele em que declara a pequenez do sedutor, daquele que visa somente o prazer fácil e transitório, desconhecedor da paixão que ameaça aniquilar o indivíduo.

No limite, Marianne expressa a necessidade da suspensão dos códigos amorosos, anunciando o amor infundado como "irrealidade" der-

${ }^{118}$ SMA, pp. 55-56, 3ème.

${ }^{119}$ SMA, pp. 172-173, 5ème.

${ }^{120} \mathrm{Na}$ mesma época em que são compostas e publicadas as Lettres encontramos esta mesma configuração na peculiar relação amorosa e literária entre Marie-Catherine Desjardins e Antoine de Villedieu. Para se manterem amantes Villedieu exige que Catherine continue a redigir uma série de cartas íntimas que, contra a sua vontade, serão publicadas. Trata-se das Lettres et Billets Galants também publicadas por Claude Barbin em 1668, cf. Julie CANDler Hayes, Reading the French Enlightenment: System and Subversion, Cambridge, Cambridge University Press, 1999, pp. 73-79. 
radeira que parece abandonar os estritos limites do amor-paixão como meio simbolicamente generalizado de codificação da vida íntima ${ }^{121}$.

Marianne anuncia também a futura alteração do centro de gravidade da construção literária da paixão amorosa que permanecera ainda segregada na "biosfera" da corte, mas que em meados do século seguinte terá de se estender retratando e respondendo às exigências da nova estrutura social.

Uma dessas exigências que as Lettres encerram é a da inserção da sexualidade enquanto mecanismo simbiótico que simboliza uma diferenciação plena no enlace amoroso. $\mathrm{O}$ autor parece ciente do tópico libertino da revelação da mulher casta. Marianne recusa de modo retrospectivo a conformidade aos códigos do pudor: “...si j' avais enfin voulu opposer ma raison à l'inclination naturelle (...) mais vous me parûtes aimable, avant que vous m'eussiez dit que vous m'aimiez, vous me témoignâtes une grande passion, j'en fus ravie, et je m'abandonnai à vous aimer éperdument..." 122 .

O que faz desta novela epistolar algo mais do que um avanço qualitativo assinalável no delinear da semântica do amor, ao mesmo tempo que a aproxima de uma evolução literária que J. Israel mapeou como Iluminismo radical -que faz remontar a Espinosa e não a Descartes como ocorre com vários historiadores feministas-, é justamente o modo como posiciona o indivíduo e a sua vivência temporal circunstancial em confronto com as expectativas normativas de distintos discursos: o moralista, o religioso e o próprio discurso literário. Acresce a isto apresentar na vivência da religiosa uma sobreposição de níveis envolvidos na paixão (corporal, emocional e comunicativo) acedendo não somente a intensidade mas também a complexidade psíquica que parece desafiar a redução do pensamento libertino a uma concepção estritamente materialista.

O discurso de Marianne apresenta múltiplas vias do discurso erótico, primeiramente daquele que começa no prazer carnal mas não se

${ }^{121}$ LuHMANN sustentou que “[o] processo [de eleição e vivência amorosa] é soberano e decide sobre a distinção que utiliza como forma de obtenção da informação (...) por isso o código do amor apaixonado não necessita de nenhuma fundamentação moral, nenhum enraizamento nas garantias permanentes da ordem social" Id., Liebe als Passion, p. 117.

${ }^{122}$ SMA, pp. 85-87, 4ème. 
dilui integralmente nele, abrindo possibilidades de relação concretizada no mundo. Aquela denúncia da pequenez do amante não deixa dúvidas quanto ao paralelismo entre as pulsões da realização erótica e o próprio percurso místico da devota. Será a substituição do objecto de amor finito (homem) pela infinitude de Jesus que se apresentará como a saída literária e biográfica de Mariana. Em todo o caso, está também aí indicada uma das modalidades da vivência erótica, quiçá a mais extrema, na medida em que se supõe elevar a existência finita a um modo de comunicação com a substância divina.

\section{Conclusão}

As discussões sobre a transição de um suposto "milagre de amor" a um "milagre de cultura" que tiveram lugar a respeito das Lettres não são de todo estranhas a um debate central da Sociologia da Arte relativo à mútua impossibilidade de, por um lado reduzir a obra às intenções do seu autor e aos pressupostos do seu próprio tempo, por outro, de a abstrair integralmente do seu horizonte histórico, supondo a sua relação não mediada com a verdade (neste caso da paixão) ou com o belo.

Vemos que nas Lettres, esse milagre de cultura, a verosimilhança do relato das afecções decorre de uma cuidada adaptação da semântica da paixão, distanciada dos discursos religioso, moralista, cortês e libertino, integrando alguns dos seus elementos estilísticos e temáticos. Essa "composição" peculiar das cartas propiciará a diferenciação das expectativas inerentes à paixão ideal e sofrimento dos amantes, contrapondo-as às que caracterizam os vínculos de interdependência próprios da amizade, do comércio e da política. É a partir da tensão entre a suposta imediação e espontaneidade da vivência emocional e a construção reflexiva da paixão e dos sinais amor, que o autor das Lettres contribui para a formação de uma nova sensibilidade estética, que acompanhará a difusão do Roman par Lettres. Esta nova estética literária depende de uma interpretação particular assente na identificação com o frémito irresistível e por vezes aniquilador da paixão de tipo amoroso, possível em grande medida pela supressão de um narrador omnisciente que desfia o guião. $\mathrm{O}$ recurso ao motivo das "cartas encontradas" logra uma indistinção entre o real e o ficcionado, permi- 
tindo uma observação dos costumes e da semântica do amor cortês, mas também a sua crítica, procedendo à revisão dos tropos da paixão e do desejo femininos.

Uma das proveniências da afectação simpática do espírito, particularmente da mulher captiva de uma emoção que a domina totalmente tem origem na literatura médica dedicada à descrição e cura da melancolia erótica. $\mathrm{O}$ trajecto que seguimos permitiu destacar alguns dos pontos onde o padecimento de Mariana está claramente moldado nessas descrições da aegritudo amoris onde se interrelacionam o sentido exterior e interior fornecendo, além do social, um dos pontos de heteroreferência da escrita que impede a sua total implosão imaginativa.

Apesar da estreita relação que manterá com a autodeterminação e com as exigências de liberdade dos sujeitos, aquilo que está em causa na nova semântica da individualidade e da coordenação das vivências dos amantes, é uma proximidade ao sofrimento físico e psíquico que deixa o sujeito cativo, uma "prisão amada" e injustificável, algo de que não se pode prestar inteiramente contas e que tinge toda a vivência pessoal. Este é um dos paradoxos do amor que, numa época marcada pelo predomínio da concepção racionalista e mecanicista do mundo, só alguns intelectuais foram capazes de valorizar, reconhecendo-o como produtivo $^{123}$.

${ }^{123}$ Luhmann, Liebe als Passion, p. 68. 
Biblos, n. s. XI (2013) 121-184

DOI: http://dx.doi.org/10.14195/0870-4112_11_5

\title{
Edmundo Balsemão Pires
}

Faculdade de Letras da UC

\section{A ARTE DA ESTÉTICA}

\section{Resumo}

Há um argumento central que o presente artigo pretende demonstrar relativamente à teoria estética. A Estética ocupa-se de determinadas tecnologias. Refiro-me, primeiramente, a uma tecnologia corporal da sensação, da memória e da imaginação mas ainda às tecnologias extracorporais, como entre outras a da Arte, que remodelam em meios externos processos sensório-motores, imaginários, do pensamento e comunicativos. A Estética como disciplina filosófica esteve historicamente dependente de fundamentações das suas descrições sobre essas tecnologias de referência nos âmbitos da Metafísica e da Filosofia da Natureza, da Gnosiologia e da Lógica e da Ética e da Política. Nas justificações não se desenvolvem só concepções gerais mas aclarações sobre o nexo dos sentidos e sobre o ideal da percepção. Uma vez liberta das condições históricas do seu ponto de partida em virtude das transformações na sua base tecnológica a Estética envereda por outros caminhos que não se podem conceber nos âmbitos justificativos indicados mas não deixam de tomar como referência uma remodelagem tecnológica dos processos sensório-motores e do pensamento.

Palavras-chave: Estética, Belo, Media, Tecnologia, Comunicação, Percepção.

\begin{abstract}
There is a central argument that this article aims to prove regarding aesthetical theory. Aesthetics deals with definite technologies. I'm referring, firstly, to a technology of the bodily sensation, memory and imagination but also to extra-corporeal technologies such as among others the Arts, remodelling in external media the sensorimotor processes, imagination, thought and communication. Aesthetics as a philosophical discipline has been historically dependent on the foundations of its descriptions of the technologies of reference in the fields of Metaphysics and the Philosophy of Nature, Theory of Knowledge and Logic and Ethics and Politics. Justifications do not involve only general
\end{abstract}


concepts but also clarifications about the nexus of the senses and the ideal of perception. Once freed from the historical conditions of its starting point because of changes in the technological focus Aesthetics turns to other ways that are inconceivable in the former supporting disciplines. Nevertheless, the modern aesthetical conceptions continue to take as a reference the technological reshaping of the sensorimotor processes and of thought.

Keywords: Aesthetics, Beauty, Media, Technology, Communication, Perception. 